Review

\title{
Bioeconomy: Markets, Implications, and Investment Opportunities
}

\author{
Manfred Kircher \\ KADIB Kircher Advice in Bioeconomy, 60431 Frankfurt am Main, Germany; kircher@kadib.de; \\ Tel.: +49-69-95104772
}

Received: 27 May 2019; Accepted: 5 July 2019; Published: 12 July 2019

\begin{abstract}
In order to achieve the objectives of the Paris Climate Change Agreement, the conversion of our economy, which is still dominated by fossil carbon, to the bioeconomy model must be completed by 2050. This requires a shift from oil, gas and coal to agricultural, forestry and marine raw materials and will affect the global processing chains for energy, fuels and chemicals. However, the land required for the production of raw materials is competing with the production of food and animal feed. In addition, future land use must better take into account planetary boundaries and the preservation of ecosystem services. In order to achieve economic, ecological and societal sustainability, the necessary measures must therefore be geared towards the UN's sustainability goals. Against this background, the future bioeconomy will have to concentrate on the food, chemical and heavy fuel sectors. Important sub-areas are alternative animal protein for nutrition, feedstock efficiency in the processing of bio-based raw materials, and the expansion of the raw materials spectrum. This requires enormous investment in industrial facilities, the integration of newly emerging value chains and the necessary infrastructure. The annual global investment requirements for renewable energy, bio-based chemicals and fuels, and ecosystem services is estimated at USD 1-2 trillion over the next three decades, equivalent to about $1.3-2.6 \%$ of global GDP. This article discusses the implications and guard rails of the bioeconomy model, as well as capital needs and possible sources.
\end{abstract}

Keywords: bioeconomy; biomass supply; bio-based feedstock; bio-based fuel; bio-based chemicals; planetary boundaries; biomass processing; competitiveness; investment criteria; investment requirements

\section{JEL Classification: 1.17}

\section{Introduction}

The Paris Climate Convention calls for achieving "a balance between anthropogenic emissions by sources and removals by sinks of greenhouse gases in the second half of this century" (UN 2015a), and in 2018, the Intergovernmental Panel on Climate Change (IPCC) reaffirmed that in order to limit global warming to $1.5{ }^{\circ} \mathrm{C}$, anthropogenic $\mathrm{CO}_{2}$ emissions must be reduced by $45 \%$ between 2010 and 2030, and to net zero by 2050 (IPCC 2018). This means that the global economy, which is still largely based on fossil raw materials, must be converted to renewable energy and carbon sources. Appropriate alternatives are offered by bio-based raw materials that can be supplied by agriculture, forestry and marine resources. The economic model based on these raw materials is known as the bioeconomy. The traditional bioeconomy is mainly integrated into the sectors of agriculture, forestry, fisheries, food and partly into the fuel and chemical industry. In the EU, it currently accounts for EUR 2 trillion or 15\% of gross national product (EU-Commission 2012); global trade in bio-based products is reported to have reached 13\% by 2014 (El-Chichakli et al. 2016). This existing bioeconomy needs to be further developed in the context of raw material change. Sillanpää and Ncibi (2017b) and 
Birner (2018) provide comprehensive overviews of the various bioeconomy concepts that focus on geopolitical, socio-economic or environmental issues, depending on the interests at stake. More than 50 countries have developed strategies for this, including Europe (German Bioeconomy Council 2018). Its vision is "a transition ( ... ) towards an optimal and renewable use of biological resources and towards sustainable primary production and processing systems. These systems will need to produce more food, fiber and other bio-based products with minimized inputs, environmental impact and greenhouse gas emissions, and with enhanced ecosystem services, zero waste and adequate societal value" (EU-Commission 2014).

It is obvious that the expansion of the bioeconomy requires enormous investment, not only in the production of bio-based raw materials, but also in global supply chains and industrial processing. In order to avoid poor investments, care must be taken not to overburden natural resources. Therefore, planetary boundaries and the preservation of ecosystem services must be taken into account. In order to achieve comprehensive sustainability, the EU's bioeconomy vision also explicitly refers to the United Nation's (UN) 2030 Agenda for Sustainable Development, which has defined 17 Sustainable Development Goals (SDG) (Table 1) (UN 2015b).

Table 1. 17 UN Sustainable Development Goals. SDG with a reference to the bioeconomy underlined. (UN 2015b modified).

\begin{tabular}{|c|c|}
\hline SDG & Goal \\
\hline 1 & No poverty \\
\hline 2 & Zero hunger \\
\hline 3 & Good-health and well-being \\
\hline 4 & Quality education \\
\hline 5 & Gender equality \\
\hline 6 & Clean water and sanitation \\
\hline 7 & Affordable and clean energy \\
\hline 8 & Decent work and economic growth \\
\hline 9 & Industry, innovation and infrastructure \\
\hline 10 & Reduced inequalities \\
\hline 11 & $\underline{\text { Sustainable cities and communities }}$ \\
\hline 12 & Responsible consumption and production \\
\hline 13 & Climate action \\
\hline 14 & Life below water \\
\hline 15 & Life on land \\
\hline 16 & Peace, justice and strong institutions \\
\hline 17 & Partnerships for the goals \\
\hline
\end{tabular}

This article first presents the challenges of the transition to the economic model of the bioeconomy and discusses the implications for the future supply of food and feed, for the stability of ecosystem services and the limits of planetary boundaries. Since raw material resources will also be limited in the bioeconomy, the priorities that can be set for bio-based products will be further discussed. It is obvious that the markets can be derived from this for long-term profitable investments. Finally, the need for investment in selected markets will be considered, and options will be discussed regarding sources from which the necessary investment funds can be procured. Overall, this article seeks to explain the potential and complexity of bio-economic value chains and to help to make robust investment decisions. 


\section{Sustainability Guard Rails}

Only two decades ago, dwindling fossil resources were considered the main driver of raw material change; since then the ecological effects of the present economic system have come to the fore. As a result, the limits of the planet's natural material cycles have been scientifically investigated for the first time, and the concept of planetary boundaries was published in 2009 (Rockström et al. 2009a, 2009b). These are intended to maintain the planet in a stable state that also tolerates changing conditions in certain fields. They were last reviewed in 2015. Figure 1 (Rockström et al. 2009b) shows the examined indicators and their current state. The water systems and the ozone layer of the stratosphere were classified as safe. The climate and the sustainability of land use, on the other hand, are classified as endangered. The state of genetic diversity and the cycle of phosphorus and nitrogen are considered disturbed (Steffen et al. 2015).

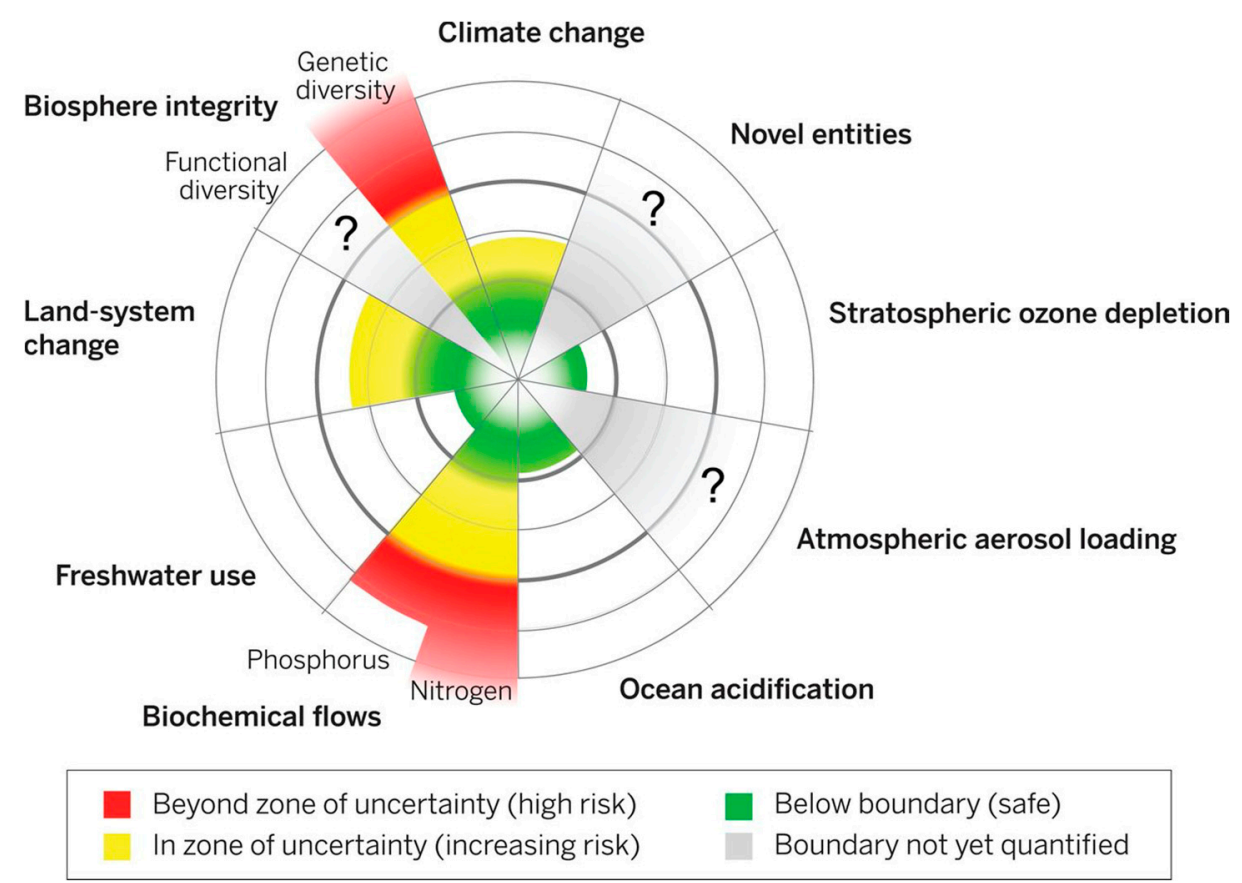

Figure 1. Planetary boundaries (Steffen et al. 2015). Permission to republish by W. Steffen.

Thus, four resources which are essential for the bioeconomy are considered to be endangered. Land use and biodiversity, as well as the plant nutrients phosphorus and nitrogen, affect agriculture and forestry in particular, and thus, the foundations of the bioeconomy. For investors, these are risk factors that must be taken into account.

The model of ecosystem services adds an economic dimension to the planetary boundaries (Costanza et al. 1997). The natural ecosystem is the basis of human well-being and economic activity. For example, it provides biomass through plant photosynthesis, irrigates agricultural land as part of the natural water cycle and pollinates plants with insects. Therefore, the ecosystem can be understood as a valuable service; it was valued by Constanza et al. at USD 125 trillion (2011) (Costanza et al. 2014). Thus, ecosystem services contribute significantly to the global gross national product (GDP) of USD 80 trillion (2017) (Statista 2018a). Possible damage to these services therefore amounts to an economic loss. Investors must understand these factors and their potential risk in order to make responsible and successful investments. Weighing up the pros and cons and choosing the right timing for an investment requires an analysis of the current situation. This will be done in the next section. 


\section{The Current Economy}

At present, the world economy is essentially based on coal, natural gas and crude oil. These fossil fuels supply energy and carbon to industries that produce electricity, heat, chemicals and fuels, as well as to heavy industry. The world oil market alone was estimated at USD 1720 billion in 2015 (Desjardins 2016). By comparison, the world market for unprocessed metals is around USD 660 billion (Desjardins 2016). Crude oil feeds the chemicals value chain, which directly generates USD 1100 billion. Taking the downstream sectors into account, chemicals contribute $7 \%$ to global GDP (USD 5.2-5.7 trillion in 2016 (Statista 2018b; CEFIC 2019)). The chemical industry is thus in a similar order of magnitude to the global food and beverages market, which is estimated at USD 5650 billion (Cision 2018).

These figures demonstrate the great economic importance of fossil energy and carbon sources. As early as 1972, the Club of Rome drew attention to the limitations of these resources (Meadows et al. 1972), and since then, oil production in particular has become more expensive. Although the need to switch to renewable resources has long been accepted in principle, in industrial and social practice, it is too often treated as an issue of the distant future. The economy has adapted to rising raw material and energy costs and adjusted product prices accordingly. Even the increasing public and political perception of $\mathrm{CO}_{2}$ emissions and climate change since the 1990s has had little influence on the growth of the fossil-based global economy (OECD 2017). Since 1990, the carbon intensity of the global economy has been reduced by only $4 \%$ (UN 2018).

The world consumes 5.1 billion tons of oil (2018) (EIA 2019a), 7.6 billion tons of coal (2017) (EIA 2019b) and 3 billion tons of natural gas (EIA 2019c) annually. The by far predominant share of $96 \%$ is used to generate energy (heat, fuel, electricity) and around $4 \%$ is used to produce chemicals (Germany, 2011) (CheManager 2013). As Germany has above-average chemical production, the share of chemicals can even be estimated to be less than $4 \%$ worldwide. Only the small share of $8 \%$ of crude oil, $1.7 \%$ of natural gas, $0.02 \%$ of coal goes into chemicals (Heede and Oreskes 2016). In spite of continuously rising production costs and advancing climate change, investments continue to be made in increasingly difficult fossil deposits. Obviously it doesn't seem easy to accept the necessary raw material change. Both the high energy and carbon density—as well as the favorable logistics—of fossil raw materials tempt us to follow the conventional path, especially since a great deal of capital is tied up in profitable and well-coordinated industrial plants. The associated value chains from raw material suppliers through producers to end markets are linked extremely efficiently by a global infrastructure of pipelines, oil and gas tankers, coal ships and railways. In this way, resource-producing countries and value-generating regions are linked together over sometimes very long distances (BPB 2014). The Middle East, the successor states of the Soviet Union and West Africa are the leading producers and exporters of oil, while Europe, Southeast Asia and China are the most important importers.

The production of chemicals is an important added value of oil; $75 \%$ of chemical production is based on the oil fraction naphtha (VCI 2017a). The leaders are China (rank 1), the EU (2) and the NAFTA countries (3) (CEFIC 2017). It is noticeable that only the NAFTA countries have their own resources; Europe and China depend almost entirely on imports.

However, a look at the UN's sustainability goals for the fossil-based economy reveals a mixed picture. On the one hand, since the beginning of the 20th century, fossil raw materials have enabled a revolutionary wave of innovation in pharmaceuticals, plastics, chemicals, energy sources and fuels. In these fields, completely new economic sectors have emerged that have created jobs and prosperity. This applies above all to the regions that generate added value, especially in the industrialized countries (Sillanpää and Ncibi 2017a).

However, this is at the expense of sustainable production and consumption (SDG 12). Today, it is clear that fossil energy is not clean (SDG 7), and therefore, that our cities, industrial plants and infrastructure are not sustainable (SDG 9, 11). The fact that access to fossil raw materials and also the benefits from their value creation are unequally distributed violates SDG 10. OPEC and OECD nations are on the winning side, but other countries are left empty-handed. Furthermore, the current economic 
system leads to a loss of ecosystem services, the financial magnitude of which is not yet adequately perceived by industry, society and politics. The loss is estimated at USD 4.3-20.2 trillion per year. Of particular relevance is the emission of $\mathrm{CO}_{2}$ (Costanza et al. 2014). In particular, the resulting climate change (SDG 13) calls for fundamental change.

\section{The Necessary Change in Raw Materials}

Since 2016 at the latest, when the Paris Climate Agreement sent a strong message, climate protection has been seen as the number one priority around the world. On 4 November 2016, the agreement was ratified by 92 states, and 163 states had already prepared climate protection programs. The limitation of global warming to below $2{ }^{\circ} \mathrm{C}$ above the pre-industrial level was binding under international law. This target requires global emissions to be reduced by $80-95 \%$ by 2050 compared with 1990 levels (EU-Commission 2011). This can only be achieved if future emissions do not exceed the so-called greenhouse gas budget of 1000 gigatons of $\mathrm{CO}_{2}$ equivalents by 2050. Even if the USA leaves the treaty as announced in 2020, the key measure of limiting emissions to the agreed emissions budget will remain (World Resources Institute 2018).

In fact, in recent years, a significant reduction has been achieved in individual regions through the introduction of renewable energies and fuels and the optimization of technical facilities and processes in energy generation, mobility and manufacturing. For example, the European Union (EU) reports to be on track to reduce emissions by $20 \%$ in 2020 compared to 1990 . Emissions were reduced by 22\% between 1990 and 2017, while the economy grew by 58\% over the same period (EU-Commission 2019). This goal was achieved by, among other factors, intensifying the bioeconomy. In Germany, for example, 9200 biogas plants are operated primarily to generate electricity (2017) (Statista 2018c). Germany consumes 2.2 million tons of wood pellets per year for heating houses (2016) (DEP 2017), and produces 738,000 tons of bioethanol (2017) (BDB 2017) as well as 1.8 million tons of biodiesel per year (2015) (FNR 2016). The German chemical industry uses 2.5 million tons of bio-based raw material per year (2015) (VCI 2017b). However, there is still a long way to go before the raw material change is complete: in 2016, the share of renewable electricity in Germany was 33\% (21\% of that bio-based (2017) (BMWi 2019), bioethanol and biodiesel reach 6.1\% in fuels (2016) (BDB 2017) and 13\% of chemical raw materials are bio-based (VCI 2017b). Although the modern, industrial bioeconomy is still in an early stage of development, it is believed to have considerable growth potential in the coming years. For example, the European Chemical Industry Council has stated that "the bioeconomy is the key to unlocking the potential of many established and new economic sectors" (CEFIC 2018). The global turnover of bio-based fuels, chemicals and polymers is expected to grow from USD 203 billion in 2015 to USD 400 billion in 2020 and USD 487 billion in 2024 (BIO 2017).

Companies in other industries are also being forced to reduce the climate footprint they create with their direct activities and that of their suppliers. An analysis of German listed companies has shown that they are on a climate path that can lead to an average global warming of $4.94{ }^{\circ} \mathrm{C}$ (2016) (right.basedonscience 2019). Leading companies have announced that they will organize their production in a climate-neutral manner. Important measures mentioned are the use of emission-free energies and compensation measures that lead to emission savings outside the company (Bosch 2019; Mercedes 2019). Carbon capture and sequestration (CCS) technologies are being discussed as another method of reducing emissions. However, due to the stoichiometric conditions, CCS has only limited capacity. $\mathrm{CO}_{2}$ is 3.67 times heavier than carbon. The combustion of 1 ton of coal, $80 \%$ of which consists of carbon, therefore produces almost 3 tons of $\mathrm{CO}_{2}$. A widespread application of CCS would therefore require a very large infrastructure.

Overall, a continuation of the previous incremental approach is therefore not sufficient. Instead, industry must prepare itself to switch consistently to non-fossil energies and carbon sources and to dispense with the exploitation of a large part of the reserves not yet mined. The remaining emissions budget of 1000 gigatons of $\mathrm{CO}_{2}$ equivalents corresponds to about one third of the $\mathrm{CO}_{2}$ potential of the 
known fossil reserves. This means that the production volume which is tolerable from the present until 2050 within the framework of the emissions budget has been named.

Overall, reserves of oil, gas and coal, which together correspond to 2700 gigatons of $\mathrm{CO}_{2}$ equivalents, are considered economically recoverable (Table 2). If, however, only 1000 gigatons may be emitted by 2050 , this means that only $37 \%$ of the reserves may be used. This total volume is divided between $70 \%$ of the known reserves of crude oil, $55 \%$ of natural gas, and $20 \%$ of coal that may still be produced (Table 2) (McGlade and Ekins 2015).

Table 2. Global reserves of coal, natural gas and crude oil (2013, Heede and Oreskes 2016), contained carbon and $\mathrm{CO}_{2}$-equivalents as reported in 2015 and to be produced by 2050 (McGlade and Ekins 2015). Gb: gigabarrel; Tcf: trillion cubic feet; Gt: gigaton).

\begin{tabular}{ccccccc}
\hline \multirow{2}{*}{$\begin{array}{c}\text { Fossil } \\
\text { Feedstock }\end{array}$} & \multicolumn{3}{c}{ Reported Reserves } & \multicolumn{2}{c}{ To Be Produced by 2050 } \\
\cline { 2 - 7 } & Volume & $\begin{array}{c}\text { Carbon } \\
\text { Contained } \\
\text { (Gigaton) }\end{array}$ & $\begin{array}{c}\mathrm{CO}_{2} \text {-Equivalents } \\
\text { (Gigaton) }\end{array}$ & $\begin{array}{c}\text { Share of } \\
\text { Total } \\
\text { Reserves }\end{array}$ & $\begin{array}{c}\text { CO }_{2} \text {-Equivalents } \\
\text { (Gigaton) }\end{array}$ & $\begin{array}{c}\text { Share of } \\
\text { Reported } \\
\text { Reserves }\end{array}$ \\
\hline Oil \& NGLs & $1688 \mathrm{~Gb}$ & 171.2 & 629.9 & $22.9 \%$ & 439 & $70 \%$ \\
\hline Natural gas & $6558 \mathrm{Tcf}$ & 95.6 & 350.4 & $12.8 \%$ & 192 & $55 \%$ \\
\hline Coal & $892 \mathrm{Gt}$ & 479.5 & 1756.9 & $64.3 \%$ & 368 & $20 \%$ \\
\hline Total & - & 746.2 & 2734.2 & $100 \%$ & 1000 & $37 \%$ \\
\hline
\end{tabular}

Consequently, firstly, two thirds of the fossil reserves stored in the ground must not be extracted. This demand has a direct impact on investment decisions that affect fossil energies, because investments that still flow into resources that cannot actually be mined in the future become a risk. This is an estimated USD 700 billion per year (Carbontracker 2013), some of which are classified as lost or have to be diverted to new investment fields. Overall, the value of stranded fossil assets is estimated at 1-4 trillion USD (Mercure et al. 2018).

The financial sector therefore sees transactions based on fossil raw materials, especially coal, as risky, and the avoidance of such transactions is increasingly becoming an instrument of risk management. In 2018, Allianz published the following decisions: "(i) Withdrawal from insuring single coal-fired power plants and coal mines in operation or planning, effective immediately; (ii) exclusion of coal risks by 2040 in Property and Casualty business and in proprietary investments; (iii) joining the Science Based Target Initiative: Commitment to the long-term development of a carbon-free economy" (Allianz Group 2018). Other financial institutions announced similar strategy changes (BNP-Paribas 2015; Bank of America 2019; Kaye 2017).

This affects all sectors associated with the production, conversion, or trading of fossil raw materials (Table 3).

\subsection{The Future Sources of Carbon}

The obvious alternative to fossil carbon sources is biomass, because fossil resources were ultimately biomass that was converted by geological processes into coal, natural gas and oil over a period of 350 million years. The combustion of today's biomass also emits $\mathrm{CO}_{2}$, but this is returned to biomass via the natural carbon cycle, and therefore, does not contribute to increasing the $\mathrm{CO}_{2}$ concentration in the atmosphere. However, biomass has two decisive disadvantages compared to fossil carbon sources: The energy and carbon density is considerably lower (Kircher 2017). This is mainly due to the high proportion of oxygen in biological materials (Table 4). 
Table 3. Industrial sectors and examples of applications based on fossil resources.

\begin{tabular}{cccccc}
\hline $\begin{array}{c}\text { Fossil Feedstock } \\
\text { Production }\end{array}$ & $\begin{array}{c}\text { Construction } \\
\text { Sector }\end{array}$ & $\begin{array}{c}\text { Chemical } \\
\text { Sector }\end{array}$ & Fuel Sector & Power Sector & Heat Sector \\
\hline Coal mining & Road surfaces & Pharma & $\begin{array}{c}\text { Automotive } \\
\text { mobility }\end{array}$ & $\begin{array}{c}\text { Electrical } \\
\text { devices }\end{array}$ & $\begin{array}{c}\text { Heavy } \\
\text { industries }\end{array}$ \\
\hline $\begin{array}{c}\text { Oil, gas production } \\
\text { Logistics (pipelines, } \\
\text { tankers) }\end{array}$ & Roofing & Automotive & Shipping & Lighting & $\begin{array}{c}\text { Industrial } \\
\text { processing }\end{array}$ \\
\hline $\begin{array}{c}\text { Oil-refining } \\
\text { Concrete }\end{array}$ & $\begin{array}{c}\text { Steel, } \\
\text { appliances }\end{array}$ & Pouskaghing & Machine fuel & Rail services & Heating offices \\
\hline & Glass & Construction & $\begin{array}{c}\text { Cooking } \\
\text { (Africa) }\end{array}$ & $\begin{array}{c}\text { Automotive } \\
\text { mobility }\end{array}$ & $\begin{array}{c}\text { Heating } \\
\text { commercial } \\
\text { buildings }\end{array}$ \\
\hline
\end{tabular}

Table 4. Composition and energy content of fossil carbon sources, biomass, sugar and vegetable oils. (Herrmann and Weber 2011; Michelsen 1941).

\begin{tabular}{ccccc}
\hline Carbon Sources & Carbon $\%$ & Hydrogen $\%$ & Oxygen $\%$ & Energy MJ/kg \\
\hline \multicolumn{5}{c}{ Fossil Carbon Sources } \\
\hline Coal & $60-75$ & 6 & $17-34$ & $25-33$ \\
\hline Gas & $75-85$ & $9-24$ & Traces & $32-45$ \\
\hline Oil & $83-87$ & $10-14$ & $0.1-2$ & 43 \\
\hline \multicolumn{7}{c}{ Biological Carbon Sources } \\
\hline Straw $^{1}$ & 44 & 6 & 50 & $10-25$ \\
\hline Wood $_{\text {Sugar }}{ }^{2}$ & 50 & 6 & 41 & $14-16$ \\
\hline Safflower oil $^{3}$ & 40 & 7 & 53 & 16 \\
\hline & 77 & 12 & 11 & 39 \\
\hline
\end{tabular}

In fact, biomass is just as suitable as fossil raw materials to generate heat and electricity and to be transformed into fuels and chemicals. Today, biomass already provides $10 \%$ of the world's energy (2016) (WEC 2017), 3\% of road transport fuel (2011) (Wackerbauer and Lippelt 2011) and 10-13\% of chemical raw materials (BIC 2016; Piotrowski et al. 2015; VCI 2017a). In particular, many elastomers, polymers, surfactants, paints and coatings, lubricants, paper and cellulose, textile fibers, pharmaceuticals and skin care products are biobased (Figure 2). Biomass can come from agricultural, forestry and marine sources, and the technologies to generate the aforementioned products are either available or under development. 

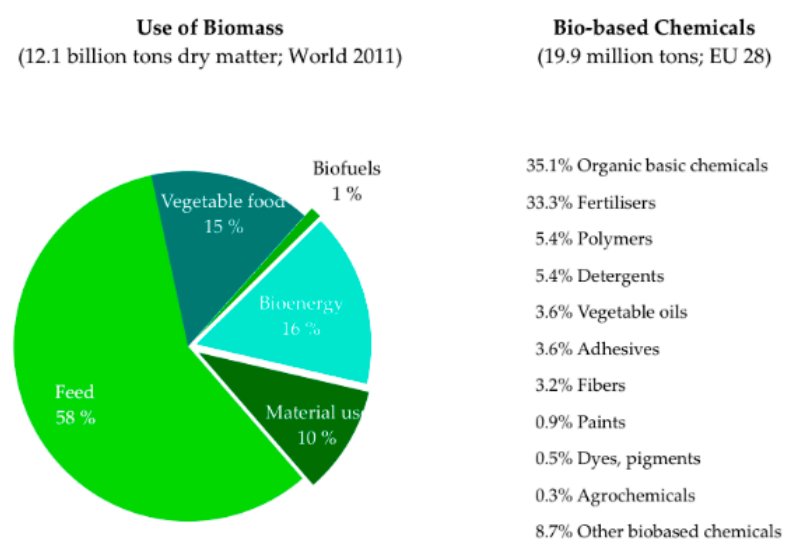

Figure 2. Use of biomass (left; Piotrowski et al. 2015) and share of biobased chemicals (right: Piotrowski et al. 2018).

However, this change in raw materials also means that the manufacturing industry is entering a raw materials market that has so far mainly served the food and feed markets. This implies an increased use of ecosystems services and, in connection with this, the observation of planetary borders becomes all the more important. Sustainability is therefore not an intrinsic property of the bioeconomy, but rather, a potential, and consequently, SDG 15 (life on land, protect, restore and promote ecosystems) is named as the SDG of highest relevance in a survey among actors of the bioeconomy (Zeug et al. 2019). In addition, there is a great need for investment in capacities for the supply of biomass, its logistics and infrastructure, as well as its implementation. Therefore, the interdependencies of the markets for food and feed, for industrial raw materials with regard to land use, biodiversity and greenhouse gas emissions are considered in the next section.

\subsection{Supply of Raw Materials}

\subsubsection{Growing Food Markets}

It is to be expected that the growing importance of biomass as an industrial raw material will have an impact on the global food supply. Although the share of biobased chemicals is still small, it accounts globally today for the consumption of about $24 \%$ of cereals and $9 \%$ of oilseeds (2017/2018) (UFOP 2017).

In the USA, more than $40 \%$ of the corn harvest is absorbed by bioethanol for the fuel market (Ossewijer et al. 2015) and sugar cane accounts for 30\% of global ethanol production (REN21 2016) of 100 billion liters (Johnson et al. 2018). The bioeconomy will entail providing considerably more renewable, mainly agricultural raw materials for use in industry. It is therefore to be expected that agriculture's share of the global GDP (currently 3.5-6.4\% depending on the data source (FAO 2018; Indexmundi 2018; Statista 2019a) will grow significantly. For comparison: The oil and gas producing sectors (only drilling) are reported to contribute 2-3\% to the World GDP (Investopedia 2018).

Even today, societies are therefore sensitive to this problem, as the "fuel versus food" discussion indicates, although only a small proportion of total biomass is used industrially. Actors in the bioeconomy therefore rank SDG 2 (zero hunger) second among the topics of the future (Zeug et al. 2019). The driving forces behind the food markets are the growing world population and increasing prosperity. By 2050, 9.8 billion people will be demanding staple foods (2017: 7.5 billion) (UN 2017), making it necessary to increase the production of cereals, pulses, tubers, milk, eggs and meat by up to $35 \%$ within the next three decades. The continuation of the increase in yield through modern plant breeding will play an important role. Since 1961, the area yield has been increased by a factor of 3 (Figure 3). The improvement of seeds, plant protection, methods of cultivation, harvesting and storage remains a never-ending task and a rewarding economic field for SDG 2. 


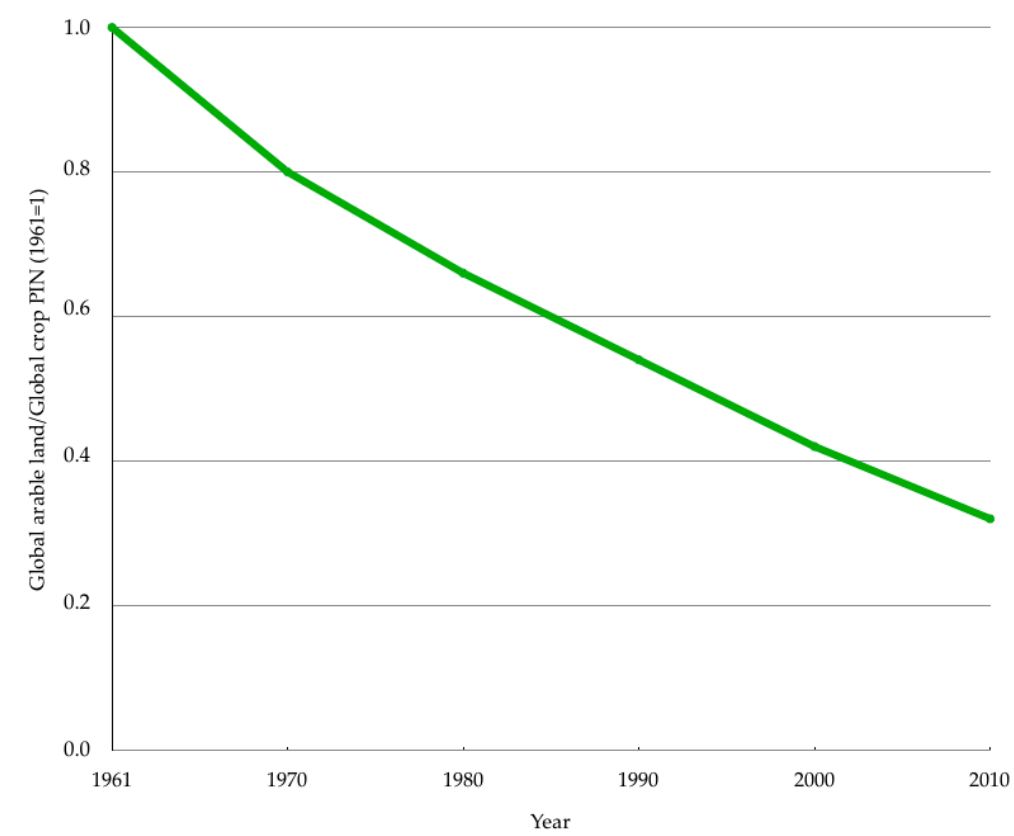

Figure 3. Crop production per arable land (PIN: Agricultural production index). (Roser and Ritchie 2018).

Among the various food markets, above-average growth is expected for meat in particular. Experience shows that the share of animal protein in a society's food is growing parallel to the development of purchasing power. Consumption in Europe with its high purchasing power is $70-90 \mathrm{~kg} / \mathrm{capita}$, while African countries with low purchasing power manage with less than $20 \mathrm{~kg} / \mathrm{capita}$ (Figure 4).

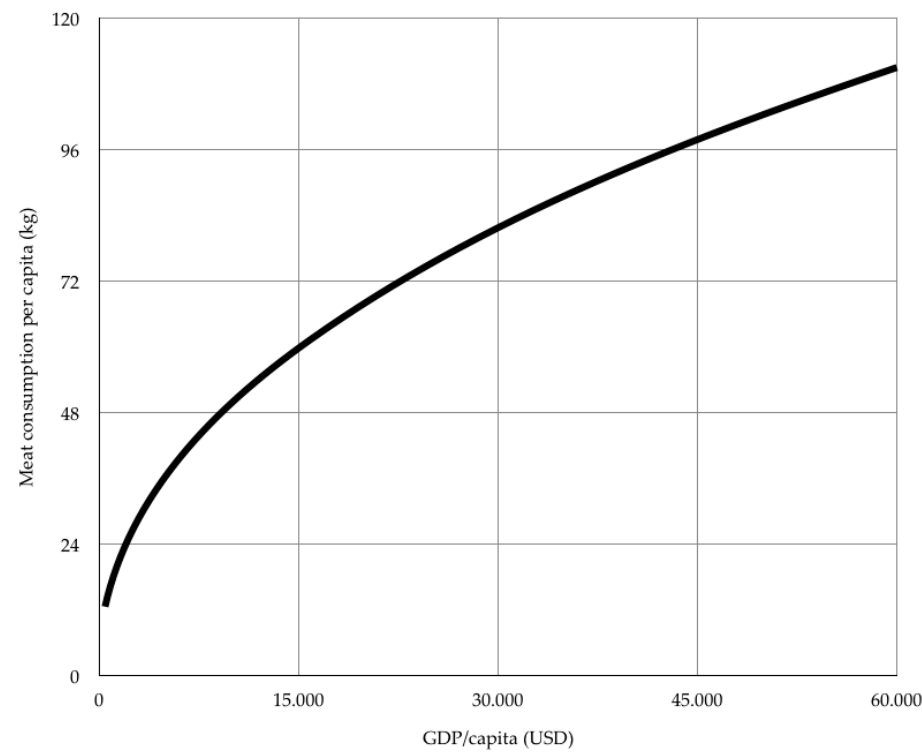

Figure 4. Meat consumption versus gross national product per capita (2013) (Roser and Ritchie 2018).

While global per capita wealth growth is expected to remain at the 1\% level observed from 1995 to 2014 (1995-2014) (Lange et al. 2018), meat consumption is expected to increase by $4.4 \%$. In 2015, 319.2 million tons of meat were produced (FAO 2016).

Compared to staple foods, meat production not only grows disproportionately, it also requires the lion's share of the production area. Worldwide, $71 \%$ of all agricultural land (Figure 5) 
(Raschka and Carus 2012) is used to feed 19 million chickens, 1.5 billion cattle, 1 billion pigs and 1 billion sheep (Reubold 2015). It therefore seems logical, in view of the necessarily increasing land use for staple foods and industrial raw materials, to promote a reduction in meat-related land use. NGOs such as Greenpeace are promoting the abandonment of meat (Greenpeace 2019). Ecological aspects such as the environmental management of liquid manure and the general issue of animal-friendly husbandry are also leading to a critical public debate in many industrialized countries about animal husbandry and meat consumption. This opens up two growth areas for the economy: On the one hand, the optimization of current methods of animal husbandry is occuring, while on the other, radical innovation (Lang et al. 2017) offers alternatives. In this way, the yield and costs of conventional animal husbandry can be further optimized by feed additives such as enzymes and amino acids. A growth market is fish farming (8.6\% AGR) (Worldwatch Institute 2018), particularly in Asia (shrimp), Norway (salmon) and Chile (tuna), which can relieve the market for wild fish and meat production on land. Multinational enterprises such as Evonik Industries (Germany) market amino acids as fish feed additives that are produced on the basis of sugar, and thus, ultimately depend on land use. Start-ups such as KnipBio and WhiteDogLabs (USA) are also working on such fish feed additives. KnipBio's process is based on methanol, which can be produced bio-based from biogas (methane); White Dog Lab's carbon source is a mixture of sugar and $\mathrm{CO}_{2}$ from the emission of bioethanol fermentation $\left(\mathrm{CO}_{2}\right)$. Atmospheric $\mathrm{CO}_{2}$ is another option when producing algae biomass as animal feed (Tzachor 2019). Other waste-based approaches include Agriprotein (NL), a company that cultivates insects on waste from the food industry, supermarkets and restaurants, and commercializes the resulting insect protein as food and feed. These examples reduce the need for land, but still fit into the conventional value chain of animal feed and animal production.
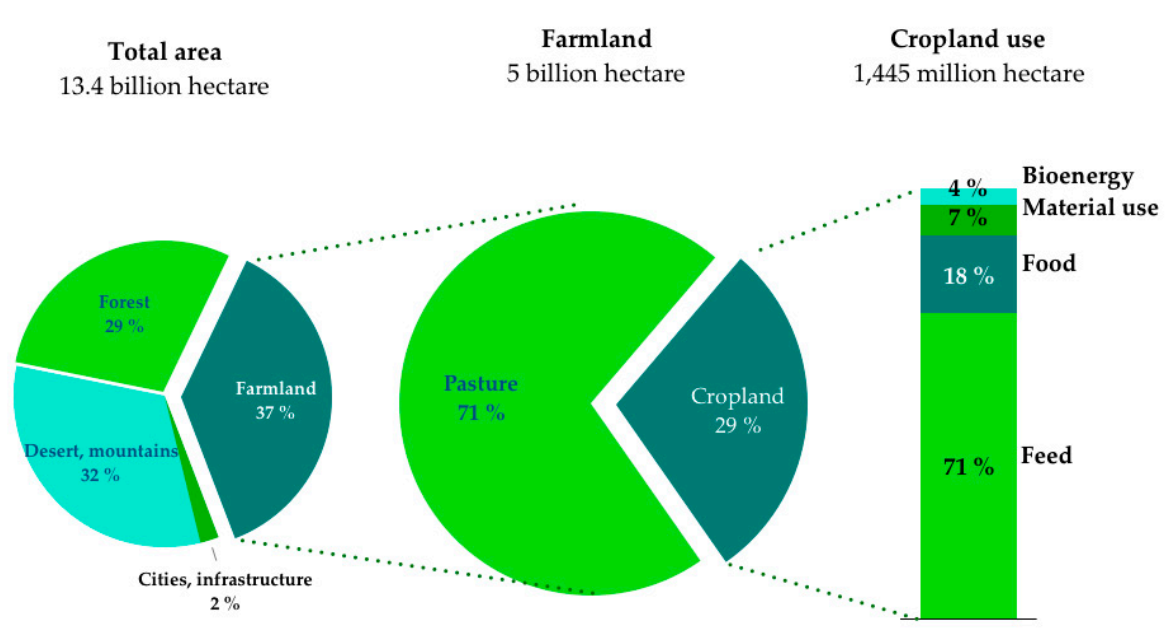

Figure 5. Global use of agricultural area (2008) (Raschka and Carus 2012; modified).

Other approaches to animal protein completely abandon animal husbandry, and therefore, represent "radical innovation". RippleFoods (USA) markets "milk" products based on pea protein and Clara Foods (USA) is developing a vegetable protein identical to chicken egg white powder protein. While these two examples do not involve animal husbandry but still depend on the cultivation of crops, Impossible Food (USA) further reduces the demand for land. This company produces tissue cultures as meat substitutes. It is to be expected that the increasing pressure to save agricultural land will give these new approaches economic potential. At the same time, the sustainability targets SDG 2 (zero hunger) and SDG 3 (well-being for people) as well as SDG 8 (decent work and economic growth), 12 (consumption and production), and 14, 15 (life below water and on land) are addressed. 


\subsubsection{Land and Land Use}

Feeding the world and replacing fossil carbon sources is a huge challenge. Only $10-22 \%$ of the global land area is fertile, has sufficient water and is in a climate zone that favors agriculture (Raschka and Carus 2012; Wortmann 2015). About 32\% of the global area is pasture, steppe and low mountain ranges, $30 \%$ is forest and $16 \%$ is settlement and other land (Wortmann 2015). While on the one hand, the demand for biomass for industrial purposes will grow strongly, on the other hand, agricultural land is threatened by overuse and climate change. Rising temperatures lead to desertification and changing precipitation intensifies soil erosion. Particularly in Sub-Saharan Africa, the Middle East and North Africa, 4.4 million $\mathrm{km}^{2}$ of agricultural land are at risk of being downgraded to "marginally suitable" or "moderately suitable" for agriculture (Zabel et al. 2014). A further factor is the increasing urbanisation from $54 \%$ of the world population in 2014 to $66 \%$ in 2050) (UN 2014). At the same time, with declining biodiversity (Johnson et al. 2017), political pressure is growing to designate more areas as nature reserves. This corresponds to the high rank given by actors in the bioeconomy to SDG 15 (protect, restore and promote ecosystems) (Zeug et al. 2019). However, the loss or renunciation of land as described above runs counter to the fact that climate change makes previously unproductive regions accessible to agriculture. Worldwide, a net increase in suitable areas of 54.2 million $\mathrm{km}^{2}$ to 58.9 million $\mathrm{km}^{2}$ is expected, especially in the northern territories of Canada, China and Russia (FAO 2015).

Of course, these developments also influence the financial valuation of agricultural and forest land. In low- and middle-income countries, the valuation of land between 1995 and 2014 has more than doubled (Wortmann 2015; Lange et al. 2018). This has led to 5-9 million $\mathrm{km}^{2}$ being developed in sub-Saharan Africa and Latin America alone (Mason et al. 2015; Woods et al. 2015), thus offering investment opportunities. Large-scale investment in fertile farmland is taking place worldwide (Statista 2013).

Maintaining the fertility of the land in the long term is an indispensable task of sustainability. This includes the responsible handling of seeds and agricultural chemicals (fertilizers, herbicides, insecticides, fungicides, etc.). Two further economic sectors that will gain importance with the bioeconomy are thus named. The global agrochemical market has a volume of USD 214.2 billion (2015, AGR 3.2\%) (MarketsandMarkets 2016) and the seed market generates USD 50 billion (2014, AGR 7.1\%) (Mordor Intelligence 2017). The fact that 2017 saw three significant transactions (ChemChina/Syngenta USD 47 billion, Dow/Dupont USD 68 billion, Bayer/Monsanto USD 64 billion) demonstrates the economic strength and potential of these industries. Biofertilizers (world market USD 946.6 million, 2015) are a niche that is growing at an above-average rate (AGR 14\%) compared to conventional fertilizers, which are produced using considerable amounts of fossil energy (Lokko et al. 2018).

Figure 6 (Roser and Ritchie 2017) shows the dependence of fertilizer consumption on farmers' incomes. In low-income African countries, consumption is less than $30 \mathrm{~kg} / \mathrm{ha}$, while in high-income Europe, $100-300 \mathrm{~kg}$ per hectare are used. Access to agrochemicals is thus an issue that affects both SDG 2 (zero hunger) and SDG10 (inequalities). At the same time, it should be remembered that the ill-considered use of fertilizers is already violating the planetary limits of the natural nitrogen and phosphate balance. From an economic point of view, the long-term supply of phosphate is a major issue. Today, phosphate is extracted by mining phosphate rock, with Morocco having the only very large deposit. The peak of production is expected in this decade. In view of the growing demand for fertilizer, the recovery of phosphate from waste water and sewage sludge, for example, is therefore becoming an economically interesting topic (USDA 2014). In Germany, for example, operators of wastewater treatment plants have been obliged to recover phosphate since 2017. This example shows how waste management is becoming increasingly important for the supply of raw materials. 


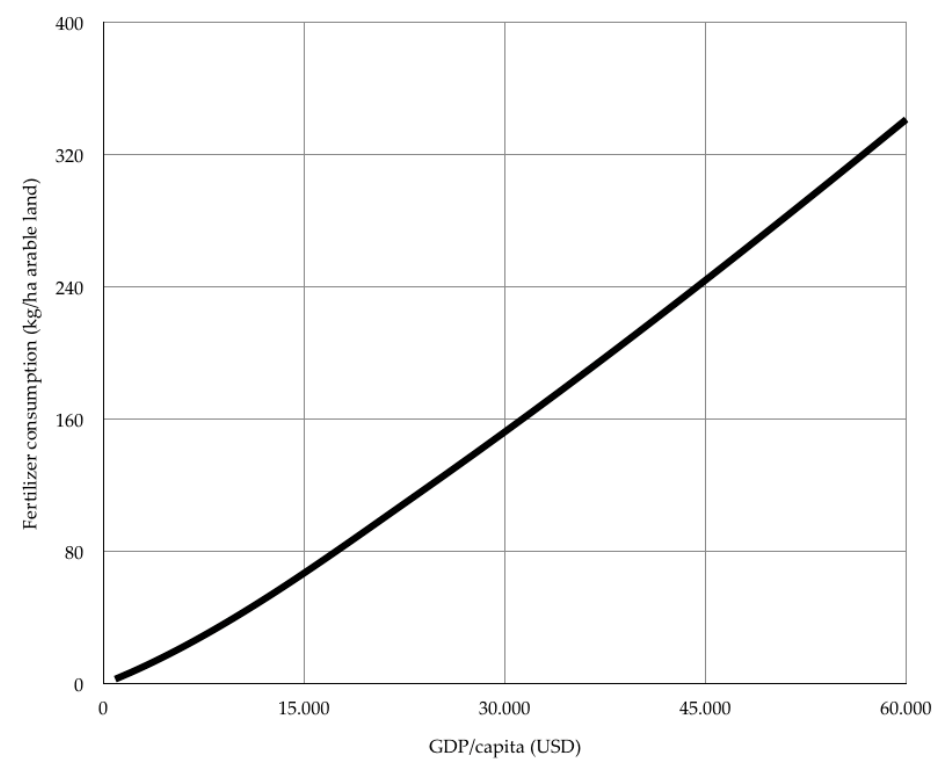

Figure 6. Fertilizer consumption per hectare versus GDP per capita, 2014 (Roser and Ritchie 2017).

Sustainability in land management and biomass use is one aspect of adherence to planetary boundaries; another is biodiversity. This is the topic of the next section.

\subsubsection{Biodiversity}

Biodiversity affects the entire biosphere, i.e., all species. Their complex interaction makes the living system stable on the one hand; on the other, isolated interventions can lead to massive disturbances of our basic living conditions. It is therefore essential to integrate the future growing production of biomass sustainably into the overall fragile ecosystem. It should be noted that extinctions are not a new phenomenon per se, but an enormously accelerated one. Worldwide species diversity has decreased by $8.1 \%$ with increasing land use over the last 500 years (Newbold and Hudson 2015), but in modern times, species extinction has accelerated by a factor of 1000 (Barnosky et al. 2011; Wilson 2016). Between 1970 and 2012, 14,152 populations of 3706 species were monitored worldwide. The resulting Global Living Planet Index documents a decline of 58\% (WWF 2017). In 2019, IPBES sounded the alarm by reporting that 1 million species are on the verge of extinction (IPBES 2019). SDG 14 and 15 (life on land and below water) are, therefore, serious issues. Today, almost no ecosystem has remained untouched by human use (Table 5) (De Groot 2010). On the other hand, protected areas of up to $50 \%$ of the land area are considered necessary for the conservation of biodiversity (Wilson 2016).

Biodiversity is also of enormous economic importance. For example, insects play a central role in the pollination of plants and in the natural nutrient cycle. It is estimated that $80 \%$ of wild plants are pollinated by insects. Insects are the beginning of the food chain for $60 \%$ of bird species. This also applies for many mammals and amphibians. All the more alarming is the worldwide decline in the diversity and population of insects. For Europe it is estimated that butterflies, bees and moths have decreased by $50 \%$ (Hallmann et al. 2017), and a German study has observed a decrease of $94 \%$ in the number of insects and 28\% in the number of species over 25 years (Vogel 2017). Figure 7 documents the drastically decreasing insect biomass of a species in a German region since 1989 (Sorg et al. 2013). This biological loss reduces the value of ecosystem services provided by insects, which is estimated at USD 57 billion annually for the US alone (Hallmann et al. 2017). With the loss of this natural service, paid workers must, for example, take over the pollination of fruit blossoms, as has already been reported from China (Goulson 2012). Ignoring the planetary boundaries is expensive. 
Table 5. Share of untouched nature in different ecosystems (De Groot 2010).

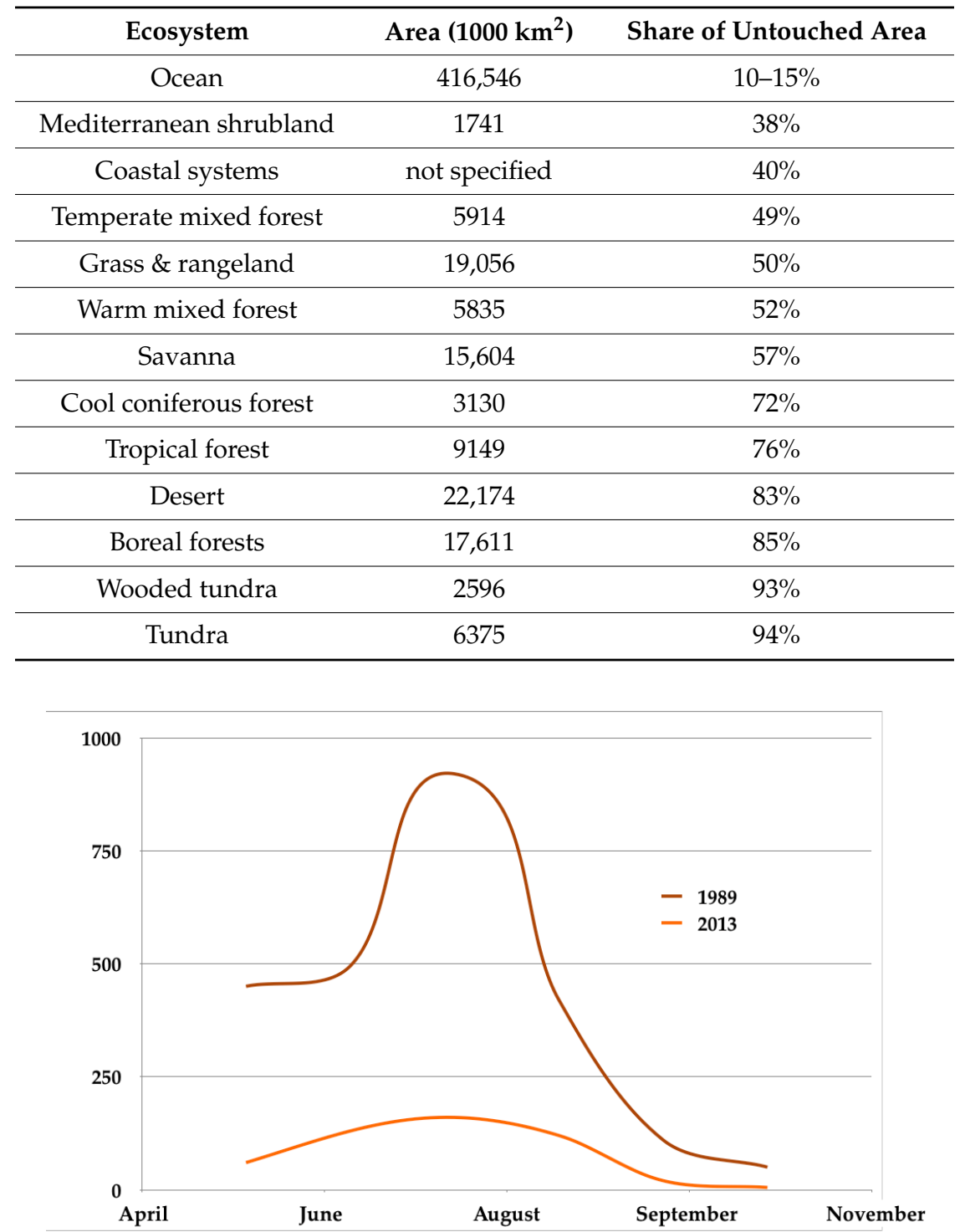

Figure 7. Insect biomass volume (hover flies) in Krefeld (Germany) throughout the year; 1989 and 2013 (Sorg et al. 2013, modified).

Agriculture, forestry and fishing must therefore recognize that they are part of and dependent on the ecosystem. To achieve sustainability, biomass production methods must be integrated into natural cycles, and must respect their limits. Depending on regional conditions, this also includes not using all the land area that could be used for the production of biomass. In accordance with SDG 12 (responsible consumption and production), the industrial use of biomass should therefore be limited to applications where there is no alternative to biomass or bio-based carbon. The markets that should be prioritized by the bioeconomy is the topic of the next section.

\section{Markets to Be Prioritised}

The prioritization of bioeconomy markets is necessary because the substitution of coal, natural gas and mineral oil places a very heavy burden on the biomass producing ecosystems. These fossil resources contain about 12 billion tons of fossil carbon. However, global agriculture produces only 7 billion tons of bio-carbon (Kircher 2012) (the total photosynthetic fixation of carbon worldwide is estimated at 120 billion tons of carbon (Effenberger 2014)). In theory, global agricultural production 
would have to be increased by a factor of 2.5 to 19 billion tons of bio-carbon to cover current fossil and bio-carbon consumption (this simplified figure only illustrates the challenge; energy content is not taken into account). In practice, the demand would be even higher because the transformation efficiency of biomass is, on average, significantly lower than that of fossil carbon sources. As already discussed, however, agriculture cannot expand indefinitely.

Therefore, the use of bio-carbon or biomass must be concentrated on markets and applications for which there is no alternative to carbon. Nutrition, which comes first, depends on vegetable carbon sources. Its priority is unquestionable (Sillanpää and Ncibi 2017a). Organic chemistry also needs carbon and must be given the second priority. This sector consumes worldwide 420 million tons of mineral oil products, 200 million tons of natural gas and 55 million tons of coal per year and produces 550 millions tons of chemicals plus 275 million tons of nitrogen-fertiliser (Levi and Cullen 2018) containing in the chemicals only about 500 million tons of carbon. Table 6 shows examples of large-volume basic chemistry from which most organic chemicals are derived (Bender 2013a, 2013b; Eramo 2018; Manesh et al. 2014; Statista 2018d, 2019b; US Grains Council 2017; Zinke 2017). For comparison, biological substances are also listed whose carbon volume also reaches the 100 million ton scale. The price of carbon of biological origin is lower than that of fossil-based molecules. However, the further processing of plant materials is more complex, which leads to comparatively high production costs (see below).

Table 6. Fossil (olefines, aromatics) and biological bulk products; global production, carbon content and cost of carbon (Bender 2013a, 2013b; Eramo 2018; Manesh et al. 2014; Statista 2018d, 2019b; US Grains Council 2017; Zinke 2017).

\begin{tabular}{ccccc}
\hline $\begin{array}{c}\text { Bulk } \\
\text { Products }\end{array}$ & $\begin{array}{c}\text { Production } \\
\text { (Mio ton) }\end{array}$ & $\begin{array}{c}\text { Carbon Content } \\
\text { (Mio ton) }\end{array}$ & $\begin{array}{c}\text { Market Price } \\
\text { (USD/ton) }\end{array}$ & $\begin{array}{c}\text { Theoretical Cost of } \\
\text { Carbon (USD/ton) }\end{array}$ \\
\hline Ethylene & 150 & 128.6 & $1200-1500$ & $1630-1750$ \\
\hline Propylene & 120 & 102.8 & $1200-1500$ & $1630-1750$ \\
\hline Methanol & 130 & 37.2 & $200-280$ & $670-980$ \\
\hline Total & 400 & 286.6 & - & - \\
\hline Benzene & 50 & Aromatics & $1300-1625$ \\
\hline Toluene & 17 & 46.1 & $1200-1500$ & $1100-1423$ \\
\hline Xylenes & 45 & 15.5 & $1000-1300$ & $1430-1770$ \\
\hline Total & 112 & 40.8 & $1300-1600$ & - \\
\hline & & 102.4 & - & 700 \\
\hline Sugar & 178 & Biologics & & - \\
\hline Lignin & 50 & 71.2 & $360-400$ & $900-1000$ \\
\hline Total & 228 & 36.0 & 500 & - \\
\hline
\end{tabular}

The energy industry is different. Solar, wind, hydro-, geothermal and nuclear energy are carbon-free. Like fossil energy, they can supply heat and thus electricity. These very large fields of consumption can therefore basically do without carbon, which is why the buzzword "decarbonization" is shaping the public debate. 
The transport sector can also switch at least in part to carbon-free fuels. Cars, which in principle can be powered by electricity or hydrogen, now run on petrol and diesel. In 2012, these two fuels accounted for $77 \%$ of total consumption for transport (Maritime Executive 2019). However, heavy goods traffic (trucks), freight shipping, and aviation will in the foreseeable future require fuel with a high energy density that is currently only available from carbonaceous fuels. Heavy goods traffic, shipping and aviation each consume around 300 million tons of diesel, marine diesel, bunker oil and kerosene annually (Concawe 2016; Indexmundi 2019; Maritime Executive 2019), i.e., a total of 900 million tons. With a carbon content of around $85 \%$, this volume contains 765 million tons of carbon. Together with the chemical industry, the sustainable supply of these prioritized markets with bio-based raw materials thus requires an additional carbon requirement of around 1.3 billion tons of carbon, which would correspond to around 2.6 billion tons of primary biomass (the different energy content is not taken into account in this estimate for simplicity's sake). The provision of such a volume of biomass seems feasible, taking into account the recycling of residues and cascade use (see below). Otherwise, the SDG 12 (responsible consumption and production) will move into the distant future.

Investors should take into account the predictable and increasing pressure to priorities biomass use, paying particular attention to carbon-free energy, bio-based chemicals and bio-based heavy-duty fuels. In particular, investment in chemicals is attractive because it generates $4-9$ times more value added than energy (EIB 2017). However, the current framework conditions relativize this advantage, because in many countries, bio-based fuels are supported by admixture quotas, but corresponding chemical products are not. Certainly, different framework conditions have an influence on the market penetration of bio-based chemicals (nova-institute 2019). The underlying competitiveness will be discussed in the next section.

\section{Industrial Practice}

\subsection{Biomass Transformation}

Previous considerations have initially focused on sustainable carbon supply in the bioeconomy. The effort and costs of processing bio-based raw materials into chemicals and fuels have not yet been taken into account. The complexity and costs of processing are a real competitive hurdle. Fossil fuels and basic chemicals are produced by simply refining mineral oil. Basic chemicals such as ethylene are easily accessible by cracking naphtha (a fraction in oil refining) (Table 7) or processing natural gas (methane). At the same time, the carbon of fossil raw materials is almost completely converted into the target product; the carbon efficiency of these processes is therefore very high. The labor intensity, on the other hand, is low. The oil refineries in the USA (total capacity 0.9 billion ton per year) (EIA 2018), offer 127,000 jobs (DATAUSA 2019). The labor intensity is thus 137 jobs/1 million tons of oil.

In contrast, biomass does not only require more processing steps (Table 7), many are technically more complex and economically more expensive and produce considerable secondary flows. To produce ethanol, sugar plants must be cultivated, harvested and the crop transported. This is followed by the refining of sugar with loss of residual biomass and finally the sugar is fermented to ethanol.

In the USA, ethanol production costs of USD 408 per ton have been reported. Taking into account the carbon credit defined in the renewable fuel standard (D6 RIN), this bioethanol would be competitive with an oil price of USD 55 per barrel (Lane 2017). Chemicals for which there is no credit system would have a competitive threshold of USD 90 per barrel oil. At the oil price level of 2013, a price of biomass in the order of USD 60 per ton was estimated to be competitive (USA) (Philp 2018). 
Table 7. Processing steps to fuel (fossil petrol, bio-ethanol) and chemicals (example ethylene) from fossil oil and biomass fractions (sugar, lignocellulose).

\begin{tabular}{|c|c|c|c|c|c|c|}
\hline \multicolumn{3}{|c|}{ Fuel } & \multirow{3}{*}{$\begin{array}{l}\text { Processing Step from } \\
\text { Feedstock to Product }\end{array}$} & \multicolumn{3}{|c|}{ Chemicals } \\
\hline \multirow{2}{*}{$\frac{\text { Fossil }}{\text { Mineral Oil }}$} & \multicolumn{2}{|c|}{ Biomass } & & \multirow{2}{*}{$\begin{array}{c}\text { Fossil } \\
\text { Mineral Oil }\end{array}$} & \multicolumn{2}{|c|}{ Biomass } \\
\hline & Sugar & Lignocellulose & & & Sugar & Lignocellulose \\
\hline Logistics & Harvesting & Harvesting & 2 & Logistics & Harvesting & Harvesting \\
\hline Refining & Logistics & Logistics & 3 & Refining & Logistics & Logistics \\
\hline- & Sugar-conversion & Saccharification & 5 & Ethylen & Sugar-conversion & Saccharification \\
\hline- & Ethanol & Sugar-conversion & 6 & - & Ethanol-conversion & Sugar-conversion \\
\hline- & - & Ethanol & 7 & - & Ethylen & Ethanol-conversion \\
\hline- & - & - & 8 & - & & Ethylen \\
\hline
\end{tabular}


The published investment costs for bioethanol from corn alone amount to USD 0.7-0.75 per liter per year, with the largest share of 38\% being spent on the processing of by-products (Cleanleap 2013). If wood-like materials (lignocellulose) are used instead of sugar, the process chain is extended by 2 further steps of preprocessing and saccharification. Investment costs will thus rise to USD 2.9 per liter of annual capacity (Tsagkari et al. 2016). If the target product is ethylene, a further chemical catalytic step will follow. Due to the complex composition of biomass and losses in processing, a carbon yield is achieved from biomass that is significantly lower than that of fossil raw materials.

The considerable personnel requirements for the production and processing of biomass must also be taken into account. Biochemicals are much more labor-intensive than biofuels due to their multi-stage conversion (Table 8) (Piotrowski and Carus 2015). EuropaBio therefore expects 900,000 to 1.5 million new jobs for the EU by 2030 (EuropaBio 2019), which at the same time confirms the higher cost level of the bioeconomy.

Table 8. Labor intensity in the production and processing of biomass (EU-28; 2011) (Piotrowski and Carus 2015, modified).

\begin{tabular}{ccc}
\hline $\begin{array}{c}\text { Producing Biomass (Jobs/1 } \\
\text { Million Tons of Biomass) }\end{array}$ & Processing Biomass (Jobs/1 Million Tons of Biomass) \\
\hline 5400 & Biofuels & 5400 \\
\cline { 2 - 3 } & Bio-Chemicals & 12,400 \\
\hline
\end{tabular}

Today, biobased chemicals are established in the fine chemicals sector, where biological raw materials and biotechnological processes often offer a technical advantage. The large market for cellulose fibers can also be attributed to the bioeconomy (nova-institute 2019). However, due to cost disadvantages, e.g., PLA (polylactic acid), a biopolymer made from sugar by NatureWorks (USA) and Total Corbion (NL), has not pushed its oil-based counterpart PET (polyethylene perephthalate) out of the market. This also applies to other sugar-based chemicals such as succinic acid (BioAmber, USA; Reverdia, Succinity, both The Netherlands), (iso-)butanol (Gevo, Butamax, both USA; Green Biologics, UK) and butanediol (Novamont, Italy). Such products are successful if the more positive life cycle assessment or specific technical properties are assessed and buyers pay a premium. In fact, there is still a small but growing market for bio-based plastics ( $2 \%$ of the total polymer market of 6.6 million tons with EUR 13 billion in 2016 (nova-institute 2017).

As mentioned, the competitiveness of such products, however, depends strongly on the oil price level or the price of biomass. At the same time, the economic challenge of using biomass becomes clear because this raw material consists of different fractions. The use of all material flows and their coupling constitutes the economic and ecological value, thus supporting the path towards sustainable industries (SDG 9), responsible consumption and production (SDG 12) and climate protection (SDG 13).

\subsection{Expansion of the Raw Materials Portfolio}

At present, primary carbon sources (sugar, vegetable oil) dominate the production of bio-based fuel and chemicals, but when it comes to truly expanding bio-based capacities, these raw materials will reach their limits. For example, global production of ethylene from sugar would require $20-50 \%$ of current arable land (Gruhlke and Bürger-Kley 2015). The expansion of the raw materials portfolio is therefore urgently needed. Sillanpää and Ncibi (2017c) published an excellent overview about feedstock options considering the local potential in the US, in Europe, and in China. In fact, companies are already exploring the suitability of alternative raw materials. Corbion Total (Netherlands) is developing PLA based on biomass residues (lignocellulose) (Laird 2016). Lignocellulosic ethanol (fuel) is already marketed in the USA (DSM/POET, Advanced Biofuels, Synata BIO; all USA) and Brazil (Granbio). Clariant (Switzerland) is building two bioethanol plants in Slovakia and Romania, each with capacities of 50,000 metric tons per year, working with wheat straw as the raw material. Energochemica (Slovakia) is also investing in a bioethanol plant in Slovakia $(55,000$ metric tons per 
year) based on lignocellulose from wheat straw, which, in addition to bioethanol, is intended to produce ethylene, ethylene oxide and lignin, as well as heat and electricity, making it a model bio-refinery. Recently, the new platform chemical levoglucosenone was introduced, which in this example is produced from wood waste (sawdust) and is to be a suitable starting material for bio-surfactants, flavors, agrochemicals, biopolymers and bio-solvents (Duncan 2019). Liquid and solid industrial and municipal by-products and waste, as well as gaseous carbon $\left(\mathrm{CO}, \mathrm{CO}_{2}\right)$, offer additional options for expanding the raw materials portfolio beyond food biomass (Table 9).

Table 9. Valorization of various bio-based feedstock options.

\begin{tabular}{|c|c|c|c|c|}
\hline Feedstock & Carbon Source & Technology & Product & $\begin{array}{l}\text { Development } \\
\text { Stage }\end{array}$ \\
\hline $\begin{array}{c}\text { Sugar cane Sugar } \\
\text { beet Starch-derived } \\
\text { Sugar }\end{array}$ & Sugar & Fermentation & $\begin{array}{l}\text { Bioethanol Amino acids } \\
\text { Enzymes Biopolymers } \\
\text { Pharmaceuticals and more }\end{array}$ & Commercial \\
\hline Woody materials & Sugar & Fermentation & Bioethanol & Commercial \\
\hline Woody materials & Wood gas & $\begin{array}{c}\text { Thermochemical } \\
\text { catalysis }\end{array}$ & Aromatics & Lab-scale \\
\hline $\begin{array}{l}\text { Liquid sewage, } \\
\text { Solid municipal } \\
\text { waste, manure }\end{array}$ & $\begin{array}{l}\text { Complex waste } \\
\text { ingredients }\end{array}$ & Fermentation & Methane & Commercial \\
\hline $\begin{array}{l}\text { Municipal solid } \\
\text { waste }\end{array}$ & Synthesis gas $(\mathrm{CO})$ & Gas-fermentation & Chemicals & Commercial \\
\hline Biogas & $\mathrm{CO}_{2}$-emission & $\begin{array}{l}\text { Gas-fermentation, } \\
\text { Algae cultivation }\end{array}$ & Methane, Chemicals & Demonstration \\
\hline $\begin{array}{c}\text { Steel mill } \\
\text { synthesis gas }\end{array}$ & $\mathrm{CO}$ & $\begin{array}{l}\text { Gas-fermentation, } \\
\text { Fischer-Tropsch }\end{array}$ & Ethanol, Hydrocarbons & Demonstration \\
\hline
\end{tabular}

Key concepts for the use of these previously neglected resources are cascade use and recycling. Cascading involves using all intermediates along the processing chain according to its material and energy value. Many processes already function in this way, but all too often, the material and energy potential is incompletely recorded. One model is the industrial location of Frankfurt (Germany) (Figure 8). A large company at this location produces biodiesel from rapeseed oil with glycerin as a by-product. This glycerin is introduced into its process line by a pharmaceutical company at the same site. Bio-waste from this pharmaceutical production and food waste from the neighboring region supply the site's biogas plant, which is one of the largest in Europe. Part of the biogas is used to generate heat and electricity for the industrial site, while another part is fed into the natural gas network. Upgrading the fraction of $\mathrm{CO}_{2}$ in biogas to methane is a future option. This cascade of material use (rapeseed oil, biodiesel, glycerin, pharmaceuticals) and energy use (heat, electricity, biogas) significantly improves raw material efficiency and the $\mathrm{CO}_{2}$ footprint and is economically viable.

Technologies that continue the cascade by using $\mathrm{CO}_{2}$ emissions from biogas plants are currently being tested on a pilot scale (biogas consists of $50-60 \%$ methane plus $40-50 \% \mathrm{CO}_{2}$ ). With the use of $\mathrm{CO}_{2}$ emissions, biogas-related $\mathrm{CO}_{2}$ emissions could be reduced to almost zero and the efficiency of raw materials increased to almost 100\%. MicrobEnergy (Germany) and Electrochaea (Switzerland) use $\mathrm{CO}_{2}$ with the addition of hydrogen to produce methane. In parallel to the biocatalysts on which these companies rely, homogeneous catalysis for the utilization of $\mathrm{CO}_{2}$ is also being investigated (Klankermayer and Leitner 2015).

Hydrogen is available by the electrolysis of water (power-2-gas). However, this is only economical if energy is available at very low cost (e.g., excess wind, solar, geothermal, hydro-power). This is an example of how the cascade use of carbon sources and renewable energies can be combined and create synergies. In the future, biogas could play a central role in carbon recycling. In fact, the global biogas market is expected to grow from USD 1.5 billion (2016) to USD 2.6 billion in 2025 (Kennedy 2019). 
The chemical industry could be integrated into the carbon cycle created in this way, because the methane contained in biogas can be further processed into methanol. Methanol is a suitable raw material for many chemical process chains (Bertau et al. 2016).

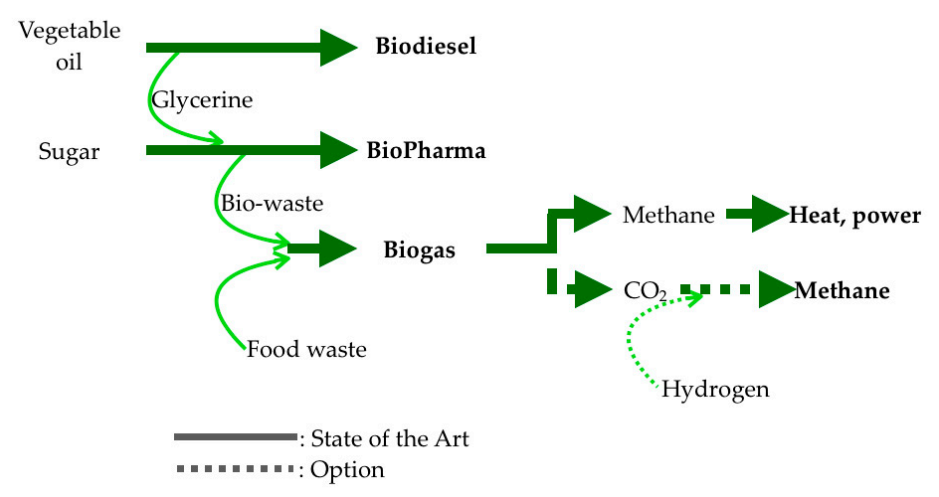

Figure 8. Cascading at an industrial location Frankfurt (Germany).

The organic fraction in household waste (MSW) offers further potential. This waste material is available in large quantities, especially in growing mega-cities and urban regions. Today, MSW is still dumped in many countries without any use. OECD countries use MSW to generate energy through incineration. The city of St. Hyacinthe (Canada) goes one step further and produces biogas from MSW. This biogas fuels the city's bus fleet and the residues from biogas fermentation are marketed as fertilizer (Ville de St. Hyacinthe 2017). New Delhi (India) also operates buses with biogas; here it is produced from waste water (The Hindu 2011).

Sekisui Chemical (Japan) and Lanzatech (USA), on the other hand, rely on chemicals. Synthesis gas obtained from MSW by gasification is converted into ethanol by fermentation. A pilot plant was commissioned in Japan in 2017 (Lanzatech 2017). The technology is of particular interest in the coming transition phase, in which fossil and increasingly bio-based raw materials are being processed, because it works with synthesis gas from both fossil and bio-based sources. In this way, the so-called learning curve with new technologies accelerates at an early stage. For example, steel mills produce and emit enormous quantities of synthesis gas based on coal. A demonstration plant for the production of ethanol from steel mill emissions is currently being built in a steel mill in Ghent (BE) (ArcelorMittal 2015). This is a real model for a "technical" carbon cycle (Kircher 2015). Carbon is not emitted into the atmosphere, but is returned to a production process. All these examples show, firstly, the potentials of recycling carbon-containing waste, secondly, the innovative power of cross-sector cooperation, and thirdly, that traditional fossil-based industries are willing to invest in carbon-recycling technologies.

The improvement of raw material efficiency, cascade use and recycling is crucial for the development of the bioeconomy and leads to the so-called closed-loop economy. This model contributes to the goals of sustainable industries and infrastructures (SDG 9), cities and municipalities (SDG 11), consumption and products (SDG 12) and climate change (SDG 13).

\subsection{The Greenhouse Gas Balance}

After discussing the complexity of the alternative feedstock portfolio, the question arises as to how effectively GHG can be reduced and how climate change (SDG 13) can actually be tackled. Table 10 shows the share of different global greenhouse gas emissions from fossil as well as non-fossil sources (USEPA 2014). 
Table 10. Share of global greenhouse gas emission compounds (fossil and non-fossil) (USEPA 2014).

\begin{tabular}{ccccc}
\hline Emission & $\mathrm{CO}_{2}$ & Methane & Nitrous Oxide & F-Gases \\
\hline Fossil & $65 \%$ & - & - & - \\
\hline Non-fossil & $11 \%$ & $16 \%$ & $6 \%$ & $2 \%$ \\
\hline
\end{tabular}

The largest share of greenhouse gases, $65 \%$, is $\mathrm{CO}_{2}$ from fossil fuels (42\%), (transport $24 \%$, industry $19 \%$, households $6 \%$, services $3 \%$ and others $3 \%$ ) (Statista 2018e). Non-fossil $\mathrm{CO}_{2}$ also contributes to the GHG balance. Soil is a living system that emits $\mathrm{CO}_{2}(11 \%)$ by nature. Methane $(16 \%)$ is released by nature from swamps and bogs as well as from livestock breeding (ruminants). Nitrous oxide (6\%) is produced in the soil when the microflora degrades synthetic nitrogen fertilizers. Fluorinated gases $(2 \%)$ are of industrial origin. Biogenic $\mathrm{CO}_{2}$, methane and nitrous oxide from agricultural activities account for $24 \%$ worldwide (Table 11) (USEPA 2014). The ecological footprint of food, feed and biomass for industrial purposes should therefore not be underestimated.

Table 11. Global greenhouse gas emissions by economic sector (USEPA 2014).

\begin{tabular}{ccc}
\hline Economic Sector & Emission Sources & Greenhouse Gas \\
\hline Energy & Power, heat generation & $25 \%$ \\
\hline Agriculture, Forestry & Crop cultivation, cattle breeding & $24 \%$ \\
\hline Industry & Production processes & $21 \%$ \\
\hline Transport & Automotive, railway, aviation, shipping & $14 \%$ \\
\hline Buildings & Air conditioning, power consumption & $6 \%$ \\
\hline Other & - & $10 \%$ \\
\hline
\end{tabular}

Not only the production, but also the processing of biomass produces greenhouse gases. Figure 9 shows greenhouse gas emissions in the bioethanol processing chain (Carvalho-Macedo et al. 2015). The largest part of the greenhouse gas is released by the steps of raw material production and ethanol fermentation, in agriculture by cultivation and fertilization, in fermentation by microbial $\mathrm{CO}_{2}$ emission, and in both steps by machines running on fossil fuels. The importance of emissions from process energy is illustrated by the fact that sugar cane ethanol emits 2.5 times less GHG than corn ethanol. The reason for this is that only the residual biomass of the sugar cane (bagasse) is suitable for generating process energy, so that the use of fossil energy can be dispensed with. A further improvement of the sugar cane energy yield is possible by producing biogas from sugar cane waste water. The Brazilian start-up SANergyo makes this a business and was awarded first prize in a multinational business plan competition (PRP USP 2017).

Biopolymers also demonstrate the significant influence of the energy source on the carbon footprint (Figure 10; (Carvalho-Macedo et al. 2015)). The use of emission-free process energies in PLA production reduces emissions by $95 \%$. The comparison of conventional PET versus bio-PLA shows that the change in the starting material also reduces greenhouse gas emissions, but only to a lesser extent. When comparing specific production costs, the advantage also lies in renewable energies. The conversion to low-carbon energy costs USD 10-200 per ton of plastic, while the use of organic raw materials leads to much higher additional costs. The importance of reducing energy consumption is also reflected in the climate protection measures planned by the chemical industry in the short term. Increasing energy efficiency and switching to renewable energies is regarded as a priority by German companies. The change in raw materials is only mentioned after that (Table 12) (Gruß 2019). 


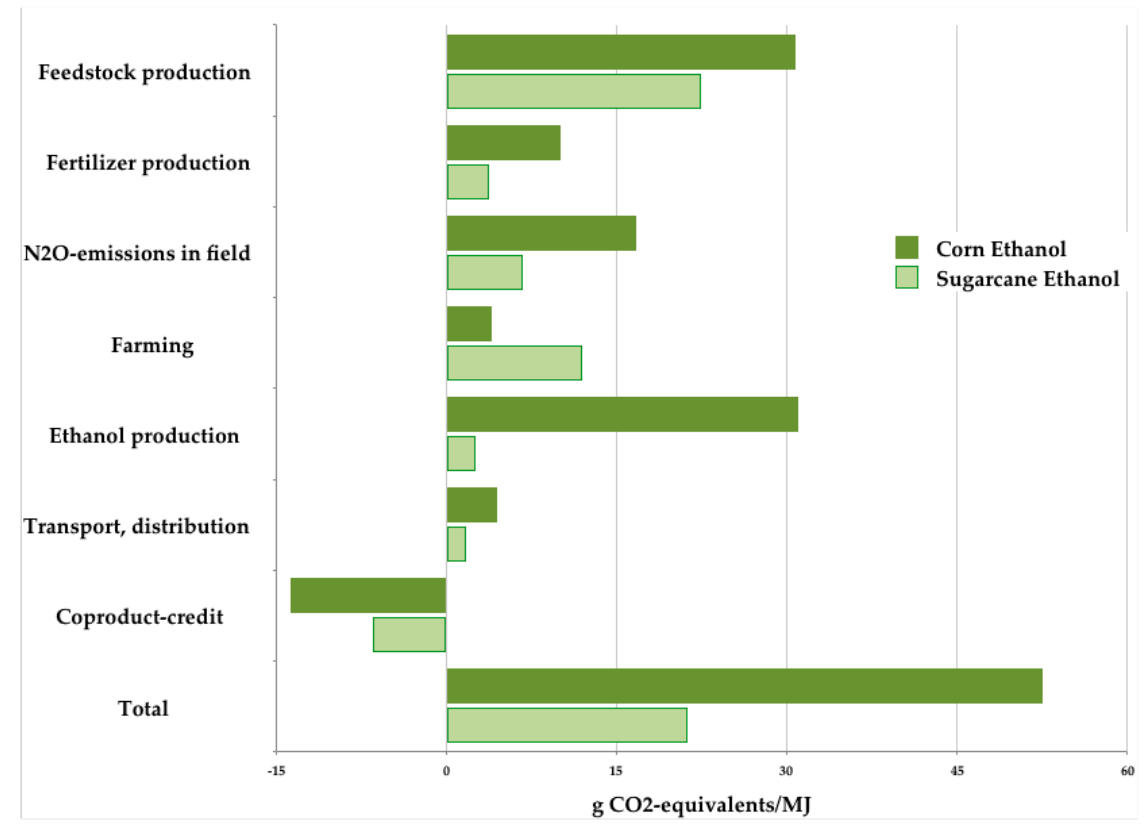

Figure 9. GHG balance of corn and sugar cane bioethanol by processing step (Carvalho-Macedo et al. 2015, modified).

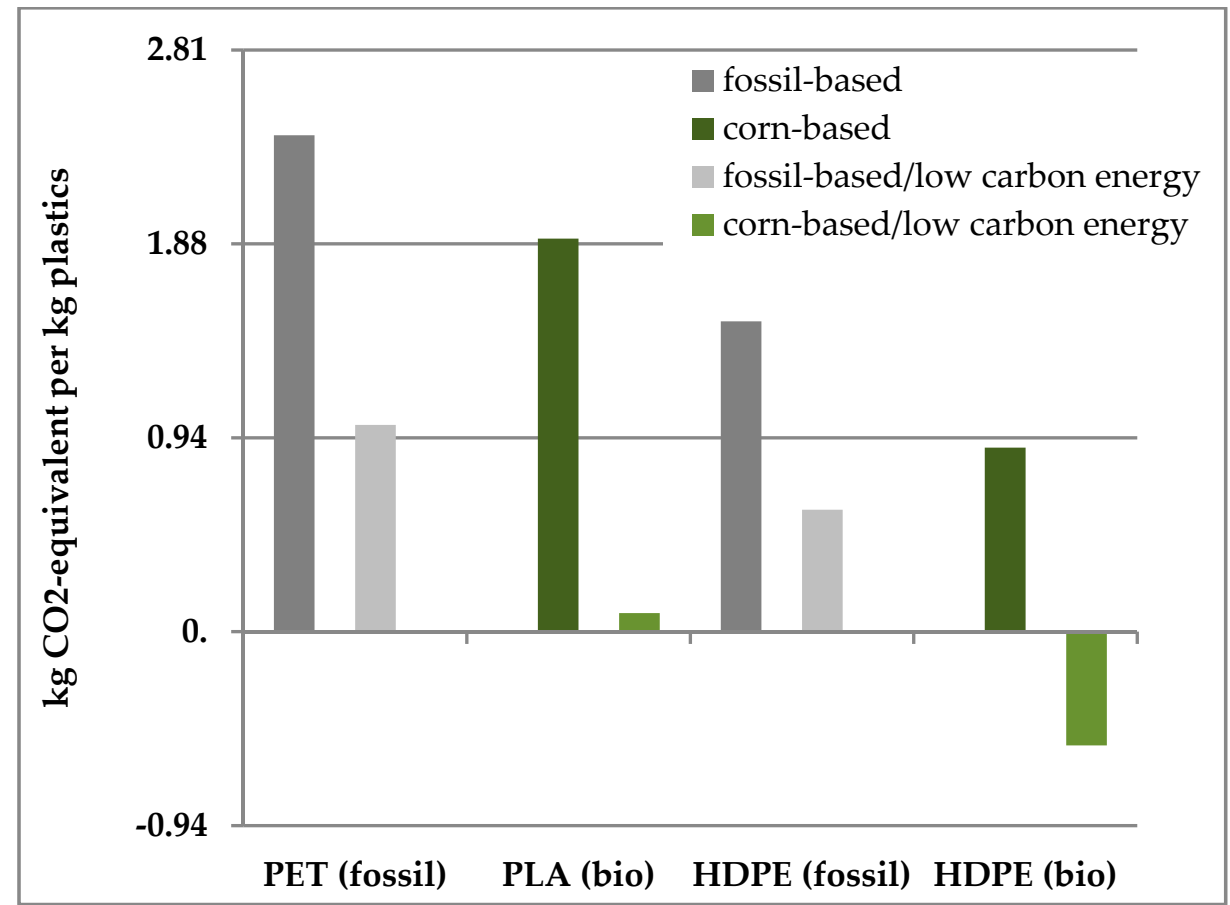

Figure 10. $\mathrm{CO}_{2}$ emissions from the production of fossil and bio-based plastics with conventional or low-carbon energy (PLA is a bio-based alternative to fossil PET; HDPE is available from fossil and bio-based raw materials) (Carvalho-Macedo et al. 2015, modified). 
Table 12. Climate protection measures announced by chemical industries (Germany; 2019) (Gruß 2019).

\begin{tabular}{cc}
\hline Measure & Planned by Chemical Industries (\%) \\
\hline Improving energy efficiency & 86 \\
\hline Optimising running processes & 81 \\
\hline Increasing the share of renewable energies & 60 \\
\hline (Increased) use of renewable raw materials & 56 \\
\hline New business models based on circular economy & 54 \\
\hline New production technologies & 51 \\
\hline Use of $\mathrm{CO}_{2}$ as carbon source & 18 \\
\hline
\end{tabular}

These examples of fuels and polymers show that fuels and chemicals from biomass currently cannot be produced without greenhouse gas footprints. Emissions are generated above all by agriculture and processing. The use of sustainable energies seems to be most effective in processing. Investors who rely on bio-derived processes and products should therefore carefully analyze the raw material source and energy intensity of a particular process and examine possibilities for process integration into emission-free energy systems.

\subsection{Value Chains and Infrastructure}

International supply chains for biomass or biomass fractions are nothing new in themselves. The German industry already processes bio-based raw materials, $62 \%$ of which come from domestic areas and 38\% from foreign areas (Kircher 2018). The same applies to Europe, which "imports" 18 million hectares per year from outside, especially from Asia. This area is equivalent to $65 \%$ of the total agricultural area used for industrial purposes (Bruckner et al. 2019).

The modern bioeconomy will intensify such supply chains considerably. Corn and soya from the USA, sugar beet from the EU, wheat from Russia, sugar cane from Brazil, palm oil from Malaysia, to give just a few examples, are future industrial goods. In the long term, therefore, the supply chains for carbon sources will start with fossil resources less in the Middle East and other regions, but will move to biomass regions. OECD countries in North America and Europe, emerging economies of the former Soviet Union, South America and Southeast Asia, and developing countries, especially in sub-Saharan Africa, will benefit. Thus, new biomass value chains can contribute to poverty reduction (SDG 1), economic growth (SDG 8) and inequality reduction (SDG 10).

Whether raw crops or biomass fractions such as starch, sugar, vegetable oil or processed products such as fuel and basic chemicals are delivered to global industrial centers depends on processing capacity in the biomass region and logistics costs. Due to the high logistics costs of biomass, transport distances to bio-refineries are kept short. Today's bio-refineries receive biomass from a radius of only 50-100 km. Due to this limited catchment area, bio-refineries are preferably built in the biomass growing regions. However, the small catchment area limits the capacity of bio-refineries that use primary biomass. Large bio-refineries have a capacity of 500,000 tons of ethanol per year (FarmProgress 2016) containing 206,000 tons of carbon. Large oil refineries, on the other hand, reach capacities in the order of 20 million tons of crude oil (Shell 2019); this corresponds to a carbon content of around 16 million tons.

Bio-refineries thus reach only $1-2 \%$ of the capacity of oil refineries. Economically, this is a significant factor, because it limits the benefits of economy of scale. Therefore, investments to improve the economic efficiency of bio-refineries and the development of capacities in biomass regions are urgently required. 


\section{Financing}

\subsection{Capital Requirements}

In view of the enormous scale of the raw material change, correspondingly high financial expenditures are necessary, especially in the areas of energy, fuel and chemicals.

As mentioned, energy should find a carbon-free future. Capacities have been built in industrialized and emerging countries since the 1990s. It is estimated that in the next 30 years, Germany will need EUR 30-60 billion annually for the energy system transformation alone (1-2\% of GDP; Acatech and Akademienunion 2017). The British House of Commons also mentions this order of magnitude for the energy system transformation in Great Britain (BBC 2019a). The EU Commission estimates that an annual investment requirement of USD 180 billion (1\% of the EU GDP of 2017) exists for the achievement of the climate target by 2030 for renovation and energy efficient buildings, renewable energy generation and transmission, and low-carbon transport, to name a few (EU-Commission 2018). The transfer of this assumption to the global economy leads to a vague estimate of about 800-1600 billion US dollars per year by 2050 (1-2\% of GDP per year; global GDP amounted to 80,000 billion USD in 2017).

Organic chemistry relies on carbon, whether from plants, lignocellulose, waste recycling or gaseous carbon sources. Investment is particularly needed in the early transformation steps from raw bio-materials to basic mass chemicals such as ethylene, propylene, methanol, benzene, toluene, xylene or new candidates for basic chemistry such as succinate. However, the subsequent steps of chemical processing into intermediates and components remain largely unchanged. Therefore, investments in raw material processing and mass chemistry are required first. The global volume of this sector is currently 550 million tons of carbon per year. Carbonaceous fuels should be phased out in the long term, but some applications where there is no carbon-free alternative will still require carbon fuel. Therefore, there is still a need for fuels, which amounts to around 900 million tons annually. Both markets, i.e., chemicals and fuels, add up to around 1500 million tons.

With an estimated investment volume of USD 1 million per 1000 tons of bio-refinery capacity (Wagemann 2012), the theoretical investment requirement is USD 1500 billion by 2050 in the chemical and fuel industry only or-if spread evenly over 30 years-around USD 50 billion per year. Taking infrastructure and other adaptation measures into account, this sum could double to the order of USD 100 billion. This would correspond to $1-2 \%$ of the worldwide turnover of the chemical industry of USD 4.8 trillion (2017) (Statista 2019c). This figure should only give an idea of the dimension required; it is far from being an accurate calculation and does not take account of technological progress, market developments and raw material supply. If declining sales of fossil raw materials disrupt or interrupt established supply chains, development could be dramatically accelerated. With this estimate, the financial sector should prepare itself to finance bio-based chemicals and fuels as well as carbon-free energy in the range of up to USD 1600 billion over 30 years-around $2 \%$ of world GDP annually. In addition, it is estimated that USD 200 to USD 400 billion per year are required to secure ecosystem services on the long term (WWF et al. 2014; Credit Suisse and McKinsey 2016). Table 13 summarizes these considerations and gives an overview of the various investment requirements. Switching to bio-based chemicals and fuels and maintaining ecosystem services is a big challenge, but also a great investment opportunity.

Table 13. Estimation of the annual investment requirements till 2050 in renewable energies, bio-based chemicals and fuels, ecosystem services (USD billion per year), and share of global GDP.

\begin{tabular}{ccccc}
\hline Investment Field & $\begin{array}{c}\text { Renewable } \\
\text { Energies }\end{array}$ & $\begin{array}{c}\text { Bio-Based Chemicals } \\
\text { and Fuels }\end{array}$ & $\begin{array}{c}\text { Ecosystem } \\
\text { Services }\end{array}$ & Total \\
\hline USD (billion per year) & $800-1600$ & $50-100$ & $200-400$ & $1050-2100$ \\
\hline Share of global GDP & $1-2 \%$ & $0.06-0.12 \%$ & $0.26-0.53 \%$ & $1.3-2.6 \%$ \\
\hline
\end{tabular}




\subsection{Supply of Capital}

There is a growing demand for the financial system to focus more on a sustainable future (UNEP 2015; FOEN 2016). In fact, investors are preparing for the post-fossil economic age and are increasingly taking sustainability criteria into account. Checking investments for compliance with SDGs is becoming a risk assessment tool (IFoA 2018). Market leaders such as BlackRock, Bloomberg, Thomson Reuters, MSCI, Standard \& Poor's and others are establishing corresponding sustainability databases and ratings. One example is the ESG Scoring Methodology (Huber et al. 2017; MSCI 2017), which analyses 37 comprehensive key issues that are broadly in line with the UN SDGs. ASN Bank (The Netherlands) is an example of a bank that has set itself a very concrete goal with a focus on biodiversity. A net positive effect on biodiversity as a result of their loans and investments should be achieved by 2030 (ASN Bank 2019). Together with other banks, a separate evaluation methodology for financial transactions has been developed (Berger et al. 2018).

An important part of the financial needs will be covered by the reallocation of investment budgets. The fossil sector should provide funding sooner rather than later to invest funds no longer needed for fossil resources in sustainable projects. The chemical industry is also expected to make a significant contribution. The chemical sector in the four top chemical nations China, USA, EU-28 and Japan invested USD 148 billion in 2016 (VCI 2018) and it can be plausibly assumed that the lion's share of this was invested in plants for fossil-based processes. Instead of investing primarily in the construction and maintenance of such plants, at least part of this funding could be used to switch to bio-based processes. Such a financial reorientation would make a significant contribution to building up the capacities required for the processing of bio-based raw materials by 2050. In fact, the industry makes such investments. In just two years (2014-2015), European companies have invested around EUR 2.2 billion in pilot and demonstration projects for bio-based fuels and chemicals (Piotrowski et al. 2016). This volume corresponds to about $10 \%$ of the investments of the chemical industry in the EU (EUR 21.7 billion in 2016) (VCI 2018).

The commercial and investment banking sector, which provides loans, is also turning to investments in bio-economic opportunities. BNP-Paribas (France) intends to invest up to EUR 15 billion in renewable energy projects by 2020 and up to EUR 100 million in start-ups focusing on energy system transformation (BNP-Paribas 2017).

Private capital will also be refocused. While in 2005, only EUR 13 billion of private money flowed into sustainability-oriented opportunities, the total amount in 2016 grew by a factor of 25 to EUR 326 billion (Austria, Germany, Switzerland) (Wagner 2017).

Another source of capital is public financing. The developed countries that are signatories to the Paris Climate Agreement announced that they would mobilize USD 100 billion for their own measures and another USD 100 billion to support developing countries (Thwaites 2015). The investment plan for Europe, the so-called Juncker Plan, aims to mobilize EUR 315 billion within three years and HORIZON2020, the EU's program for research, development and innovation, provides EUR 80 billion (2014-2020), with a focus on sustainable energies, fuels and chemicals.

Additional grants are provided by charitable foundations. The Bill \& Melinda Gates Foundation supports research \& development in sustainable agriculture with USD 300 million over the next three years (Gates Foundation 2017). Gates is joined by a co-founder of the Breakthrough Energy Coalition, which focuses on low greenhouse gas and sustainable electricity, transportation, agriculture, manufacturing and buildings (Breakthrough Energy 2019).

Public funding and private grants go primarily to research and development projects (Technology Readiness Level (TRL) 5-7). In the financing of pilot (TRL 7-8) and demonstration plants (TRL 8-9), this share decreases in favor of private financing (Figure 11) (EIB 2017). 


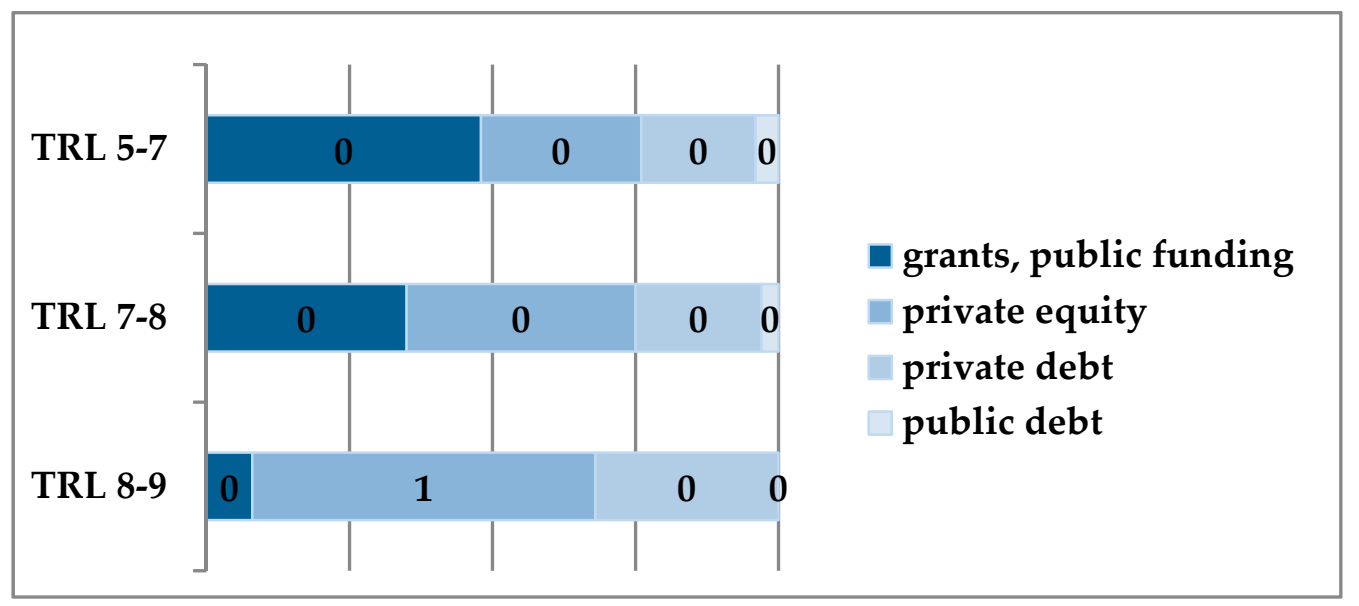

Figure 11. Average weighted capital structure of bioeconomy start-ups by TRL (EIB 2017, modified).

The aforementioned financial resources demonstrate that funds are available and that industry is in principle willing to invest. However, the general business climate and economic and regulatory conditions are still favorable to conventional behavior. A strong factor is the subsidies for fossil energies in tax policy, which are estimated at USD 5.3 trillion worldwide (Coady et al. 2015). The transfer of part of these financial resources to the development and implementation of the bioeconomy would significantly improve its competitive position and the conditions for achieving the SDG.

\section{Investment Timing}

The public and politicians are increasingly pushing to speed up the process of raw material change. Young people are committed to climate protection, as the student demonstrations under the motto "Fridays for future" show, and the Irish and British parliaments declared a climate emergency in 2019 (BBC 2019b). Furthermore, the industry itself is already feeling the effects of climate change and is taking measures. For example, the unusual drought in Germany in 2018 had such a severe impact on BASF's raw material supply and production that the consolidated result amounted to losses of EUR 250 million. $73 \%$ of German chemical companies therefore declare the reduction of $\mathrm{CO}_{2}$ emissions to be a corporate goal (Gruß 2019). In principle, bio-based raw materials and processing technologies are available to supply the markets under discussion (nova-institute 2019). The appropriate time for investment, of course, depends on competitiveness and framework conditions.

For fuels, the EIA complains that the increase in capacity is not in line with the self-imposed target of 200 million tons of oil equivalent by 2025 (EIA 2019d). This is mainly due to the political framework conditions. On the one hand, bio-fuels are only profitable through mandatory admixing quotas, and on the other, the EU has capped the admixtures (EU-Commission 2016). Therefore investment opportunities in these fields will arise as soon as the framework conditions permit. However, this dependency also entails a risk, as politically defined framework conditions can undergo unexpected changes and jeopardize a business case.

The same applies to basic chemicals. Although small capacities already exist, competitiveness is developing only hesitantly for further expansion. However, in Europe, for example, the price of emission certificates has risen significantly, and a general taxation of $\mathrm{CO}_{2}$ emissions is increasingly being discussed. Both factors will increase the attractiveness of investments in such production facilities.

Beside solid feedstocks, the use of carbon monoxide and $\mathrm{CO}_{2}$ as gaseous carbon sources appears attractive. Due to the large volume of emissions, the production of large-volume bulk chemicals from gaseous carbon sources is of particular interest. One cost hurdle at present, however, is the high energy requirement of such processes. Only when the supply of volatile energies (wind and solar energy) is so large that the storage of cheap excess energy in chemical products is worthwhile can economic 
efficiency be expected. The networking of the chemical and energy sectors therefore determines the right time for investments here.

Many bio-based fine and specialty chemical products based on conventional bio-based raw materials such as sugar and vegetable oils are already competitive and commercially successful due to their functionality, thus offering worthwhile investment targets.

\section{Conclusions}

In order to achieve the objectives of the Paris climate agreement, a reorganization of the carbon processing industry is unavoidable. Changing the raw material base, applying more sustainable practices, adapting infrastructure and implementing new supply and value chains are major challenges, but also major opportunities. Figure 12 shows that the priority markets for food, chemicals, fuels and energies offer rewarding investment opportunities. The nutrition markets will of course remain bio-based. For the other sectors, i.e., chemical and energy production, which today are predominantly supplied by fossil raw materials, the product areas that are dependent on carbon must be prioritized. This applies in particular to the organic chemistry sector, whose products by definition contain carbon. For the energy sectors, it must be demanded that priority be given to building up capacities for emission-free energies. For technical reasons, however, bio-based carbon fuels will also have to make a contribution in the foreseeable future, and at the end of the usage cascade, part of the bio-based residual flows will also be used to generate heat and power. It is obvious that in the sense of sustainable investment, the boundary conditions of the bioeconomy, such as planetary limits and the preservation of ecosystem services, must be taken into account.

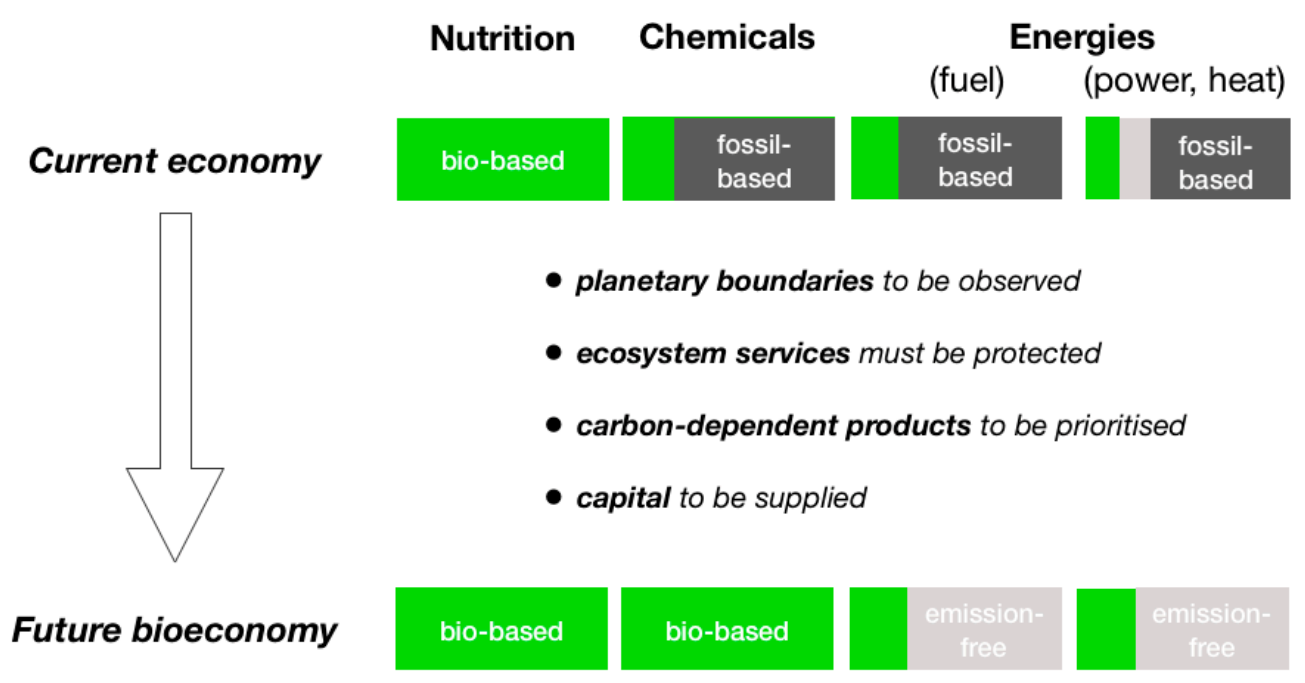

Figure 12. Markets affected by the transition to the bio-economy and framework conditions to be observed.

For this reason, investors are increasingly taking the comprehensive criteria of the UN SDG into account in project evaluations and risk analyses. Recently, a global expert survey was published that highlighted 5 SDGs as critical factors: SDG 12: responsible consumption and production; SDG 9: industry, innovation and infrastructure; SDG 13: climate action; SDG 7: affordable and clean energy; and SDG 11: sustainable cities and communities. Conflicts of interest are seen above all in the fields of non-food uses of arable land, use of crop land to produce feed, and land use change (Issa et al. 2019).

Societies, governments and industries are increasingly aware of the urgency of driving forward the transition to a bioeconomy. Emission-free energy and bio-based materials have already begun to develop large and growing markets. Nevertheless, bio-based raw materials and products are too often not competitive in comparison with fossil-based alternatives. Politicians are therefore called upon to create framework conditions that incorporate the damage caused by the present economic 
system into the costs of fossil-based products. The financial sector already perceives these damages as a risk. Investors now have a responsibility to identify profitable business cases in the bioeconomy and promote them sustainably.

Funding: This research received no external funding.

Conflicts of Interest: The author declares no conflict of interest.

\section{References}

Acatech, Leopoldina, and Akademienunion. 2017. Sektorkopplung—Optionen für die Nächste Phase der Energiewende (Schriftenreihe zur Wissenschaftsbasierten Politikberatung). Berlin: Königsdruck, ISBN 978-3-8047-3672-6.

Allianz Group. 2018. Allianz Is Driving Change toward a Low-Carbon Economy with an Ambitious Climate Protection Package. Available online: https://www.allianz.com/en/press/news/business/insurance/180504allianz-announces-climate-protection-package.html (accessed on 12 May 2019).

ArcelorMittal. 2015. ArcelorMittal, LanzaTech and Primetals Technologies Announce Partnership to Construct Breakthrough $€ 87 \mathrm{~m}$ Biofuel Production Facility. Available online: http://corporate.arcelormittal.com/newsand-media/news/2015/july/13-07-2015 (accessed on 12 May 2019).

ASN Bank. 2019. Net Positive Effect on Biodiversity in 2030. Available online: https://www.asnbank.nl/over-asnbank/duurzaamheid/biodiversiteit/biodiversity-in-2030.html (accessed on 9 July 2019).

Bank of America. 2019. Coal Policy. Available online: https://about.bankofamerica.com/assets/pdf/COAL_POLICY. pdf (accessed on 12 May 2019).

Barnosky, Anthony D., Nicholas Matzke, Susumu Tomiya, Guinevere O. Wogan, Brian Swartz, Tiago B. Quental, Charles Marshall, Jenny L. McGuire, Emily L. Lindsey, Kaitlin C. Maguire, and et al. 2011. Has the Earth's sixth mass extinction already arrived? Nature 471: 51-57. [CrossRef] [PubMed]

BBC. 2019a. UK Parliament Declares Climate Change Emergency. Available online: https://www.bbc.com/news/ uk-politics-48126677 (accessed on 21 May 2019).

BBC. 2019b. Climate Change: Ireland Declares Climate Emergency. Available online: https://www.bbc.com/news/ world-europe-48221080 (accessed on 13 May 2019).

BDB Bundesverband der Deutschen Bioethanolwirtschaft. 2017. Die Deutsche Bioethanolwirtschaft in Zahlen. Available online: https://bdbe.de/daten/marktdaten-deutschland (accessed on 12 May 2019).

Bender, Michael. 2013a. Global Supply and Demand of Petrochemical Products Relied on LPG as Feedstock. Available online: http://www.lpgc.or.jp/corporate/information/program5_Japan2.pdf (accessed on 21 May 2019).

Bender, Michael. 2013b. Global Aromatics Supply—Today and Tomorrow. Available online: https://www.dgmk. de/petrochemistry/abstracts_content21/Bender.pdf (accessed on 21 May 2019).

Berger, Joshua, Mark Jacob Goedkoop, Wijnand Broer, Roel Nozeman, Collette D. Grosscurt, Milena Bertram, and Franck Cachia. 2018. Common Ground in Biodiversity Footprint Methodologies for the Financial Sector. Paris, October 3. Available online: https://www.google.com/search?client=safari\&rls=en\&q=Berger, $+\mathrm{J}$. ;+Goedkoop, +M.J.;+Broer, +W; ++Nozeman, +R;+Grosscurt, +C.D.;+Bertram, + +M.,+Cachia,,+ F.;Common+ ground+in+biodiversity+footprint+methodologies+for+the+financial+sector, + Paris, $+3+$ October, $+2018 \&$ ie $=$ UTF-8\&oe=UTF-8 (accessed on 22 May 2019).

Bertau, Martin, Heribert Offermanns, Ludolf Plass, Friedrich Schmidt, and Hans-Jiirgen Wernicke, eds. 2016. Methanol: The Basic Chemical and Energy Feedstock of the Future. Heidelberg, New York, Dordrecht and London: Springer.

BIC. 2016. European Bioeconomy 2013: €2.1 Trillion Turnover and 18.3 Million Employees. Available online: http://biconsortium.eu/sites/biconsortium.eu/files/news-image/BIC_PressRelease_Bioeconomy2013_ 3March2016.pdf (accessed on 21 May 2019).

BIO. 2017. The Biobased Economy: Measuring Growth and Impacts. Available online: https://www.bio.org/sites/ default/files/Biobased_Economy_Measuring_Impact.pdf (accessed on 21 May 2019).

Birner, R. 2018. Bioeconomy concepts. In Bioeconomy—Shaping the Transition to a Sustainable, Biobased Economy. Edited by Iris Lewandowski. Cham: Springer Nature, pp. 17-38.

BMWi. 2019. Erneuerbare Energien. Available online: https://www.bmwi.de/Redaktion/DE/Dossier/erneuerbareenergien.html (accessed on 21 May 2019). 
BNP-Paribas. 2015. Financing and Investment Policies: Coal-Fired Power Generation-Sector. Available online: https://group.bnpparibas/uploads/file/csr_sector_policy_cfpg.pdf (accessed on 21 May 2019).

BNP-Paribas. 2017. BNP Paribas Takes Further Measures to Accelerate Its Support of the Energy Transition. Available online: http://bnpparibas.de/en/2017/10/11/bnp-paribas-takes-further-measures-to-accelerate-itssupport-of-the-energy-transition/ (accessed on 21 May 2019).

Bosch. 2019. Climate Action: Bosch to Be Carbon Neutral Worldwide by 2020. Available online: https://www.boschpresse.de/pressportal/de/en/climate-action-bosch-to-be-carbon-neutral-world-wide-by-2020-188800.html (accessed on 24 May 2019).

BPB. 2014. Handelströme Erdöl. Available online: http://bpb.de/nachschlagen/zahlen-und-fakten/globalisierung/ 52535/handelsstroeme-erdoel (accessed on 21 May 2019).

Breakthrough Energy. 2019. Manufacturing a Brighter Tomorrow. Available online: http://b-t.energy/landscape/ manufacturing/ (accessed on 19 May 2019).

Bruckner, Martin, Tiina Häyhä, Stefan Giljum, Victor Maus, Günther Fischer, Sylvia Tramberend, and Jan Börner. 2019. Quantifying the global cropland footprint of the European Union's non-food bioeconomy. Environmental Research Letters 14: 045011. Available online: https://iopscience.iop.org/article/10.1088/1748-9326/ab07f5 (accessed on 12 May 2019). [CrossRef]

Carbontracker. 2013. Unburnable Carbon Wasted Capital and Stranded Assets. Available online: https: //carbontracker.org/reports/unburnable-carbon-wasted-capital-and-stranded-assets/ (accessed on 19 May 2019).

de Carvalho-Macedo, Isaias, André M. Nassar, Annette L. Cowie, Joaquim E. A. Seabra, Luisa Marelli, Martina Otto, Michael Q. Wang, and Wallace E. Tyner. 2015. Greenhouse Gas Emssions from Bioenergy. In Bioenergy $\mathcal{E}$ Sustainability: Bridging the Gaps SCOPE 72. Edited by Glaucia Mendes Souza, Reynaldo L. Victoria, Carlos A. Joly and Luciano M. Verdade. Paris: SCOPE, pp. 582-617.

CEFIC. 2017. World Chemical Sales Geographic Breakdown. Available online: http://fr.zone-secure.net/13451/ 451623/?startPage=14\#page=5 (accessed on 20 May 2019).

CEFIC. 2018. Bioeconomy. Available online: http://www.cefic.org (accessed on 21 May 2019).

CEFIC. 2019. Chemical Industry Contributes \$5.7 Trillion to Global GDP and Supports 120 Million Jobs, New Report Shows. Available online: https://cefic.org/media-corner/newsroom/chemical-industry-contributes-5-7trillion-to-global-gdp-and-supports-120-million-jobs-new-report-shows/ (accessed on 11 May 2019).

Cision. 2018. Food and Beverages Global Market Report 2018. Available online: https://www.prnewswire.com/ news-releases/food-and-beverages-global-market-report-2018-300602932.html (accessed on 4 May 2019).

CheManager. 2013. Rohstoffe in der Chemischen Industrie. Weinheim: CHEManager, pp. 13-14. Available online: https://www.chemanager-online.com/news-opinions/grafiken/rohstoffe-der-chemischen-industrie (accessed on 19 May 2019).

Cleanleap. 2013. Conventional Bioethanol Production Cost. Available online: http://cleanleap.com/4-bioethanol/ 42-conventional-bioethanol-production-costs (accessed on 11 May 2019).

Coady, David, Ian Parry, Louis Sears, and Baoping Shang. 2015. How Large Are Global Energy Subsidies? IMF Working Paper WP/105/105. Available online: http://www.imf.org/en/publications/wp/issues/2016/12/31/how-largeare-global-energy-subsidies-42940 (accessed on 20 May 2019).

Concawe. 2016. Marine Fuel Facts. Available online: https://www.concawe.eu/wp-content/uploads/2017/01/ marine_factsheet_web.pdf (accessed on 9 May 2019).

Costanza, Robert, Ralph d'Arge, Rudolf de Groot, Stephen Farber, Monica Grasso, Bruce Hannon, Karin Limburg, Shahid Naeem, Robert V. O'Neill, Jose Paruelo, and et al. 1997. The value of the world's ecosystem services and natural capital. Nature 387: 253-60. [CrossRef]

Costanza, Robert, Rudolf de Groot, Paul Sutton, Sander van der Ploeg, Sharolyn J. Anderson, Ida Kubiszewski, Stephen Farber, and R. Kerry Turner. 2014. Changes in the global value of ecosystem services. Global Environmental 26: 152-58. [CrossRef]

Credit Suisse, and McKinsey. 2016. Conservation Finance-From Niche to Mainstream: The Building of an Institutional Asset Class. Available online: https://assets.rockefellerfoundation.org/app/uploads/ 20160121144045/conservation-finance-en.pdf (accessed on 22 May 2019).

DATAUSA. 2019. Petroleum Refining. Available online: https://datausa.io/profile/naics/32411/ (accessed on 3 May 2019). 
DEP. 2017. Entwicklung Pelletproduktion in Deutschland. Available online: http://.depv.de/de/home/marktdaten/ entwicklung_pelletproduktion/ (accessed on 21 May 2019).

Desjardins, Jeff. 2016. The Oil Market Is Bigger Than All Metal Markets Combined. Available online: https: //www.visualcapitalist.com/size-oil-market/ (accessed on 4 May 2019).

Duncan, Tony. 2019. Extracting value from waste biomass by creating renewable chemicals. Industrial Biotechnology 15: 63-64. [CrossRef]

Effenberger, Franz Xaver. 2014. Vison: "Technical Photosynthesis". In Methanol: The Basic Chemical and Energy Feedstock of the Future. Edited by Martin Bertau, Heribert Offermans, Ludolf Plass, Friedrich Schmidt and Hans Jürgen Wernicke. Heidelberg, New York, Dordrecht and London: Springer, pp. 39-50.

EIA. 2018. Short-Term Energy Outlook. Available online: https://www.eia.gov/outlooks/steo/report/global_oil.php (accessed on 20 May 2019).

EIA. 2019a. Short-Term Energy Outlook. Available online: https://www.eia.gov/outlooks/steo/report/global_oil.php (accessed on 12 May 2019).

EIA. 2019b. Coal 2018, Analysis and Forecasts to 2023. Available online: https://www.iea.org/coal2018/ (accessed on 12 May 2019).

EIA. 2019c. Natural Gas. Available online: https://www.eia.gov/outlooks/ieo/pdf/nat_gas.pdf (accessed on 12 May 2019).

EIA. 2019d. Biofuels for Transport. Available online: https://www.iea.org/tcep/transport/biofuels/ (accessed on 13 May 2019).

EIB. 2017. Access-to-Finance Conditions for Investments in Bio-Based Industries and the Blue Economy. Available online: http://www.eib.org/attachments/pj/access_to_finance_study_on_bioeconomy_en.pdf (accessed on 20 May 2019).

El-Chichakli, Beate, Joachim von Braun, Christine Lang, Daniel Barben, and Jim Philp. 2016. Five cornerstones of a global bioeconomy. Nature 535: 221-23. Available online: https:/www.nature.com/news/policy-fivecornerstones-of-a-global-bioeconomy-1.20228 (accessed on 11 May 2019). [CrossRef] [PubMed]

Eramo, Mark. 2018. Global Ethylene Market Outlook: Low Cost Feedstocks Fuel the Next Wave of Investments in North America and China. IHS Chemical. Available online: http://media.corporate-ir.net/media_files/IROL/ 11/110877/05_Global_Ethylene_Market_Outlook_Eramo.pdf (accessed on 20 May 2019).

EU-Commission. 2011. A Roadmap for Moving to a Competitive Low Carbon Economy in 2050. Available online: http://.cbss.org/wp-content/uploads/2012/12/EU-Low-Carbon-Road-Map-2050.pdf (accessed on 21 May 2019).

EU-Commission. 2012. Innovating for Sustainable Growth-A Bioeconomy for Europe. Available online: https://publications.europa.eu/en/publication-detail/-/publication/1f0d8515-8dc0-4435ba53-9570e47dbd51 (accessed on 21 May 2019).

EU-Commission. 2014. Food Security, Sustainable Agriculture and Forestry, Marine, Maritime and Inland Water Research and the Bioeconomy. Available online: https:/ec.europa.eu/programmes/horizon2020/en/h2020section/food-security-sustainable-agriculture-and-forestry-marine-maritime-and-inland-water (accessed on 19 May 2019).

EU-Commission. 2016. Renewable Energy—Recast to 2030 (RED II). Available online: https://ec.europa.eu/jrc/en/ jec/renewable-energy-recast-2030-red-ii (accessed on 22 May 2019).

EU-Commission. 2018. Final Report 2018 by the High-Level Expert Group on Sustainable Finance. Available online: https:/ec.europa.eu/info/sites/info/files/180131-sustainable-finance-final-report_en.pdf (accessed on 21 May 2019).

EU-Commission. 2019. Progress Made in Cutting Emissions. Available online: https:/ec.europa.eu/clima/policies/ strategies/progress_en (accessed on 4 May 2019).

EuropaBio. 2019. Jobs and Growth Generated by Industrial Biotechnology in Europe. Available online: https://www.europabio.org/industrial-biotech/publications/jobs-and-growth-generated-industrialbiotechnology-europe (accessed on 22 May 2019).

FAO. 2018. Global Trends in GDP, Agriculture Value Added, and Food-Processing Value Added (1970-2016). Available online: http://www.fao.org/economic/ess/ess-economic/gdpagriculture/en/ (accessed on 22 May 2019).

FarmProgress. 2016. The Five Largest Ethanol Producers. Available online: https://www.farmprogress.com/ market-reports/afternoon-market-recap-may-10-2019 (accessed on 12 May 2019). 
FAO. 2015. Soils Are Endangered, but the Degradation Can Be Rolled Back. Available online: http://fao.org/news/ story/en/item/357059/icode/ (accessed on 20 May 2019).

FAO. 2016. Food Outlook. Available online: https://weltagrarbericht.de/fileadmin/files/weltagrarbericht/ GlobalAgriculture/02Hunger/FoodOutlook10_2016.pdf (accessed on 20 May 2019).

FNR. 2016. Entwicklung Biodiesel Produktion und Absatz in Deutschland. Available online: https://biokraftstoffe. fnr.de/kraftstoffe/biodiesel/ (accessed on 20 May 2019).

FOEN. 2016. Proposals for a Roadmap towards a Sustainable Financial System in Switzerland. Available online: http://www.sustainablefinance.ch/upload/cms/user/20160614_Proposals_for_a_Roadmap_ FOEN.pdf (accessed on 19 May 2019).

Gates Foundation. 2017. \$306 Million Commitment to Agricultural Development. Available online: https://gatesfoundation.org/Media-Center/Press-Releases/2008/01/\%24306-Million-Commitment-toAgricultural-Development (accessed on 31 January 2019).

German Bioeconomy Council. 2018. Update Report about National Strategies around the World-Bioeconomy Council (Part III). Berlin: Bioeconomy Council, Available online: https://biooekonomierat.de/fileadmin/Publikationen/ berichte/GBS_2018_Bioeconomy-Strategies-around-the_World_Part-III.pdf (accessed on 12 May 2019).

Goulson, Dave. 2012. Decline of Bees Forces China's Apple Farmers to Pollinate by Hand. Available online: https://www.chinadialogue.net/article/show/single/en/5193-Decline-of-bees-forces-Chinas-apple-farmers-to-pollinate-by-hand (accessed on 20 May 2019).

Greenpeace. 2019. Eating Less Meat, More Plants Helps the Environment. Available online: https://www. greenpeace.org/usa/sustainable-agriculture/eco-farming/eat-more-plants/ (accessed on 4 May 2019).

De Groot, Rudolf. 2010. Integrating the ecological and economic dimensions in biodiversity and ecosystem service valuation. In The Economics of Ecosystems and Biodiversity Ecological and Economic Foundations. Edited by Pushpam Kumar. London and Washington: TEEB Earthscan, Available online: http:/www.teebweb.org/wp-content/uploads/2013/04/D0-Chapter-1-Integrating-theecological-and-economic-dimensions-in-biodiversity-and-ecosystem-service-valuation.pdf (accessed on 20 May 2019).

Gruß, Andrea. 2019. Klimawandel ist Gefahr und Chance Zugleich. Weinheim: CHEManager, p. 4.

Gruhlke, Martin, and Walter Bürger-Kley. 2015. Chemie oder Teller. CheManager. Available online: http: //www.chemanager-online.com/themen/konjunktur/chemie-oder-teller (accessed on 20 May 2019).

Hallmann, Caspar A., Martin Sorg, Eelke Jongejans, Henk Siepel, Nick Hofland, Heinz Schwan, Werner Stenmans, Andreas Müller, Hubert Sumser, Thomas Hörren, and et al. 2017. More than 75 percent decline over 27 years in total flying insect biomass in protected areas. PLOS ONE 12: e0185809. [CrossRef] [PubMed]

Heede, Richard, and Naomi Oreskes. 2016. Potential Emissions of $\mathrm{CO}_{2}$ and Methane from Proved Reserves of Fossil Fuels: An Alternative Analysis. Global Environmental Change 36: 12-20. [CrossRef]

Herrmann, Michael, and Jürgen Weber. 2011. Öfen und Kamine. Raumheizungen Fachgerecht Planen und Bauen. Berlin: Beute Verlag.

Huber, Betty Moy, Michael Comstock, and Davis Polk. 2017. Reports and Ratings: What They Are, Why They Matter. Harvard Law School Forum on Corporate Governance and Financial Regulation. Davis Polk $\mathcal{E}$ Wardwell LLP. July 27. Available online: https://corpgov.law.harvard.edu/2017/07/27/esg-reports-and-ratingswhat-they-are-why-they-matter/ (accessed on 20 May 2019).

IFoA. 2018. Actuaries Seek to Contribute to Sustainable Development Goals. Available online: https://actuaries.org.uk/news-and-insights/media-centre/media-releases-and-statements/actuariesseek-contribute-sustainable-development-goals (accessed on 20 May 2019).

Indexmundi. 2018. World GDP—Composition by Sector. Available online: https://www.indexmundi.com/world/ gdp_composition_by_sector.html (accessed on 22 May 2019).

Indexmundi. 2019. World Jet Fuel Consumption by Year. Available online: https://www.indexmundi.com/energy/ ?product=jet-fuel (accessed on 9 May 2019).

Investopedia. 2018. What Percentage of the Global Economy Consists of the Oil and Gas Drilling Sector? Available online: https://www.investopedia.com/ask/answers/030915/what-percentage-global-economy-comprisedoil-gas-drilling-sector.asp (accessed on 22 May 2019).

IPBES. 2019. One million species face extinction. Nature 569: 171. Available online: https://www.nature.com/ articles/d41586-019-01448-4 (accessed on 19 May 2019). 
IPCC. 2018. Special Report on Global Warming of $1.5^{\circ} \mathrm{C}$. Available online: https://www.ipcc.ch/report/sr/15/ (accessed on 11 May 2019).

Issa, Irwa, Sebastian Delbrück, and Ulrich Hamm. 2019. Bioeconomy from Expert's Perspectives-Results of a Global Expert Survey. Available online: https://journals.plos.org/plosone/article?id=10.1371/journal.pone. 0215917\#pone.0215917.ref002 (accessed on 11 May 2019).

Johnson, Christopher N., Andrew Balmford, Barry W. Brook, Jessie C. Buettel, Mauro Galetti, Lei Guanchun, and Janet M. Wilmshurst. 2017. Biodiversity losses and conservation responses in the Anthropocene. Science 356: 270-75. [CrossRef] [PubMed]

Johnson, Francis X., Manoel Regis Lima Verde Leal, and Anne Nyambane. 2018. Sugarcane as a renewable resource for sustainable futures. In Achieving Sustainable Cultivation of Sugarcane. Edited by Philippe Rott and Burleigh Dodds. Cambridge: Science Publishing, pp. 1-23.

Kaye, Leon. 2017. Triple Pundit; Blackrock Investments “Coal Is Dead". Available online: https://.triplepundit. com/2017/06/blackrock-coal-dead/ (accessed on 20 May 2019).

Kennedy, Helena Tavares. 2019. Biomethane Business Is Booming_From Waste to Watts and Wonder Chemicals. Available online: http://www.biofuelsdigest.com/bdigest/2019/05/12/biomethane-business-is-booming-fromwaste-to-watts-and-wonder-chemicals/ (accessed on 21 May 2019).

Kircher, Manfred. 2012. The transition to a bioeconomy: Emerging from the oil age. Biofuels, Bioproducts and Biorefining 6: 369-75. [CrossRef]

Kircher, Manfred. 2015. Sustainability of biofuels and renewable chemicals production from biomass. Current Opinion in Chemical Biology 29: 26-32. [CrossRef] [PubMed]

Kircher, Manfred. 2017. Fundamental biochemical and biotechnological principles of biomass growth and use. In Introduction to Renewable Biomaterials. Edited by Ali S. Ayoub and Lucian A. Lucia. Hoboken: Wiley, pp. 1-38.

Kircher, Manfred. 2018. Implementing the bioeconomy in a densely populated and industrialised country. Advances in Industrial Biotechnology 1: 3-11. [CrossRef]

Klankermayer, Jürgen, and Walter Leitner. 2015. Love at second sight for $\mathrm{CO}_{2}$ and $\mathrm{H}_{2}$ in organic synthesis. Science 350: 629-30. [CrossRef] [PubMed]

Laird, Karen. 2016. Corbion Seeks Allies on Alternative Feedstock for PLA Project. Available online: https://plasticstoday.com/materials/corbion-seeks-allies-on-alternative-feedstock-plaproject/90242661225277 (accessed on 20 May 2019).

Lane, Jim. 2017. Ethanol and Biodiesel: Dropping below the Production Cost of Fossil Fuels? Biofuels Digest. Available online: https://www.biofuelsdigest.com/bdigest/2017/05/18/ethanol-and-biodiesel-droppingbelow-the-production-cost-of-fossil-fuels/ (accessed on 19 May 2019).

Lang, Christine, Hannelore Daniel, Regina Birner, and Martin Reich. 2017. Bioökonomie für eine Nachhaltige Proteinversorgung-Zur Bedeutung Tierischer Produkte und Biobasierter Innovationen. Bioökonomierat. Available online: http://biooekonomierat.de/fileadmin/Publikationen/berichte/Hintergrundpapier_zur_ Proteinproblematik_final.pdf (accessed on 23 May 2018).

Lange, Glenn-Marie, Quentin Wodon, and Kevin Carey. 2018. The Changing Wealth of Nations 2018, Building a Sustainable Future. World Bank Group. Available online: https:/openknowledge.worldbank.org/bitstream/ handle/10986/29001/9781464810466.pdf? sequence=2\&isAllowed= (accessed on 6 February 2018).

Lanzatech. 2017. From Trash to Tank: Upcycling of Landfill to Fuel Demonstrated in Japan. Available online: https://openknowledge.worldbank.org/bitstream/handle/10986/29001/9781464810466.pdf?sequence=2\& isAllowed=http://www.lanzatech.com/trash-tank-upcycling-landfill-fuel-demonstrated-japan/ (accessed on 16 February 2018).

Levi, Peter G., and Jonathan M. Cullen. 2018. Mapping Global Flows of Chemicals: From Fossil Fuel Feedstocks to Chemical Products. Environmental Science E Technology 52: 1725-34. [CrossRef]

Lokko, Yvonne, Marc Heijde, Karl Schebesta, Philippe Scholtès, Marc van Montagu, and Mauro Giacca. 2018. Biotechnology and the bioeconomy-Towards inclusive and sustainable industrial development. New Biotechnology 40A: 5-10. [CrossRef] [PubMed]

Manesh, Ali, Kevon Tabrizi, and Teng Yang. 2014. Lignin and Economics of Lignocellulosic Biomass Fractionation. Available online: https://www.bio.org/sites/default/files/lignin-economic-lignocellulosic-fractionation_ali_ manesh_0.pdf (accessed on 22 February 2018). 
Maritime Executive. 2019. Transport Uses 25 Percent of World Energy. Available online: https://www.maritimeexecutive.com/article/transport-uses-25-percent-of-world-energy (accessed on 9 May 2019).

MarketsandMarkets. 2016. Agrochemicals Market by Type (Fertilizers \& Pesticides), Fertilizer Type (Nitrogenous, Potassic, \& Phosphatic), Pesticide Type (Organophosphates, Pyrethroids, Neonicotinoids, and Bio-Pesticides), Sub-Types \& Crop Type- Global Trends \& Forecast to 2020. Available online: https://www.marketsandmarkets. com/Market-Reports/global-agro-chemicals-market-report-132.html?gclid=Cj0KCQiA2Y_ UBRCGARIsALglqQ1WLbCJ7PgUD3mQXEj7CwbDJdeYUsC0SQ4zjd0ulKLck4MJT9tnQHsaAhd8EALw_ wcB (accessed on 13 February 2018).

Mason, P. Michael, Katherine Glover, J. Andrew C. Smith, Kathy J. Willis, Jeremy Woods, and Ian P. Thompson. 2015. The potential of CAM crops as a globally significant bioenergy resource: Moving from 'fuel or food' to 'fuel and more food'. Energy E Environmental Science 8: 2320-29.

McGlade, Christophe, and Paul Ekins. 2015. The geographical distribution of fossil fuels unused when limiting global warming to $2{ }^{\circ} \mathrm{C}$. Nature 517: 187-90. [CrossRef]

Meadows, Donella H., Dennis L. Meadows, Jørgen Randers, and William W. Behrens III. 1972. The Limits of Growth. New York: Universe Books.

Mercedes. 2019. Ambition2039: Our Path to Sustainable Mobility. Available online: https://blog.daimler.com/en/ 2019/05/13/mercedes-carbon-neutral-e-mobility/ (accessed on 24 May 2019).

Mercure, Jean-Francois, Hector Pollitt, Jorge E. Viñuales, Neil R. Edwards, Philip B. Holden, Unnada Chewpreecha, Pablo Salas, Ida Sognnaes, Alice Lam, and Florian Knobloch. 2018. Macroeconomic impact of stranded fossil fuel assets. Nature Climate Change 8: 588-93. Available online: https://www.nature.com/articles/s41558-0180182-1 (accessed on 22 May 2019). [CrossRef]

Michelsen, Ejnar Rolf. 1941. Beitrag zur Chemie des Torfes, Dessen Schwelung und Extraktion. Ph.D. Thesis, Eidgenössische Technische Hochschule in Zürich, Zürich, Switzerland.

Mordor Intelligence. 2017. Seed Industry-Global Trends, Market Advancements and Forecasts to 2022. Available online: https://www.mordorintelligence.com/industry-reports/seeds-industry (accessed on 23 February 2018).

MSCI. 2017. ESG Ratings Methodology. Available online: https://msci.com/documents/10199/123a2b2b-1395-4aa2a121-ea14de6d708a (accessed on 31 January 2018).

Newbold, T., and L. N. Hudson. 2015. Global effects of land use on local terrestrial biodiversity. Nature 520: 45-50. [CrossRef]

nova-institute. 2017. Bio-Based Polymers Worldwide: Ongoing Growth Despite Difficult Market Environment. Available online: http://news.bio-based.eu/bio-based-polymers-worldwide-ongoing-growthdespite-difficult-market-environment/ (accessed on 13 February 2018).

nova-institute. 2019. The State of the European Bio-Based Economy Is Very Mixed, the Market Is in a Critical Phase. Available online: http://news.bio-based.eu/michael-carus-ceo-of-nova-institute-in-an-interview-with-biobased-news-on-the-european-bio-based-economy-and-a-shift-towards-a-renewable-carbon-economy/ (accessed on 9 May 2019).

OECD. 2017. Economic Outlook June 2017. Available online: http://.oecd.org/eco/outlook/Better-but-notgood-enough-press-handout-summary-of-projections-oecd-economic-outlook-june-2017.pdf (accessed on 9 February 2018).

Ossewijer, Patricia, Helen K. Watson, Francis X. Johnson, Mateus Batistella, Luis A. B. Cortez, Lee R. Lynd, Stephen R. Kaffka, Stephen P. Long, Hans van Meijl, Andre M. Nassar, and et al. 2015. Bioenergy and food security. In Bioenergy \& Sustainablity: Bridging the Gaps. Edited by Glaucia M. Souza, Reynaldo L. Victoria, Carlos A. Joly and Luciano Martins Verdade. Sao Paulo: SCOPE, vol. 72, pp. 90-137.

Philp, Jim. 2018. The bioeconomy, the challenge of the century for policy makers. New Biotechnology 40: 11-19. [CrossRef]

Piotrowski, Stephan, Michael Carus, and Roland Essel. 2015. Global Bioeconomy in the Conflict between Biomass Supply and Demand. Nova Paper \#7 on Bio-Based Economy 2015-2010. Available online: http: //agricultura.gencat.cat/web/.content/de_departament/de02_estadistiques_observatoris/27_butlletins/02_ butlletins_nd/documents_nd/fitxers_estatics_nd/2015/0165_2015_ERenovables_Biomassa_biomassa.pdf (accessed on 20 May 2019). 
Piotrowski, Stephan, and Michael Carus. 2015. A New Study by Nova-Institut: EU-28 Bioeconomy Is Worth 2 Trillion Euro, Providing 19 Million Jobs. Available online: http://news.bio-based.eu/a-new-study-by-novainstitut-eu-28-bioeconomy-is-worth-2-trillion-euro-providing-19-million-jobs/ (accessed on 24 February 2018).

Piotrowski, Stephan, Michael Carus, and Dirk Carrez. 2016. European Bioeconomy in Figures. Available online: http://biconsortium.eu/sites/biconsortium.eu/files/downloads/20160302_Bioeconomy_in_figures.pdf (accessed on 20 May 2019).

Piotrowski, Stephan, Michael Carus, and Dirk Carrez. 2018. European Bioeconomy in Figures 2008-2015, Contribution of NACE Classes to the Total Product Volume of Bio-Based Chemicals, EU-28, 2008-2015). Available online: https://biconsortium.eu/sites/biconsortium.eu/files/documents/Bioeconomy_data_2015_ 20150218.pdf (accessed on 19 May 2019).

PRP USP. 2017. Projeto de Produção de Energia a Partir de Efluentes Vence Etapa Nacional da G-BIB. Available online: http://prp.usp.br/projeto-de-producao-de-energia-a-partir-de-efluentes-vence-etapa-nacional-dag-bib/ (accessed on 24 February 2018).

Raschka, Achim, and Michael Carus. 2012. Stoffliche Nutzung von Biomasse-Basisdaten für Deutschland, Europa und die Welt. Erster Teilbericht zum F+E-Projekt "Ökologischekologische Innovationspolitik-Mehr Ressourceneffizienz und Klimaschutz Durch Nachhaltige Stoffliche Nutzung von Biomasse", FKZ 371093 109. Hürth: nova-Institut $\mathrm{GmbH}, \mathrm{p} .26$.

REN21. 2016. Renewables 2016 Global Status Report. Renewable Energy Policy Network for the 21st Century. Paris: REN21, p. 272.

right.basedonscience. 2019. By How Many ${ }^{\circ} \mathrm{C}$ Would the Earth Warm Up to by 2050 If Every Company Were as Emission-Intensive as. Available online: https://www.xdegreecompatible.de/en (accessed on 24 May 2019).

Rockström, Johan, Will Steffen, Kevin Noone, Åsa Persson, F. Stuart Chapin III, Eric Lambin, Timothy M. Lenton, Marten Scheffer, Carl Folke, Hans Joachim Schellnhuber, and et al. 2009a. Planetary boundaries: Exploring the safe operating space for humanity. Ecology and Society 14: 32-43. Available online: http://ecologyandsociety. org/vol14/iss2/art32/ (accessed on 3 February 2018).

Rockström, Johan, Will Steffen, Kevin Noone, Åsa Persson, F. Stuart Chapin III, Eric F. Lambin, Timothy M. Lenton, Marten Scheffer, Carl Folke, Hans Joachim Schellnhuber, and et al. 2009b. A safe operating space for humanity. Nature 461: 472-75. [CrossRef] [PubMed]

Reubold, Todd. 2015. These Maps Show Changes in Global Meat Consumption by 2024. Here's Why That Matters. Available online: https://ensia.com/articles/these-maps-show-changes-in-global-meat-consumption-by2024-heres-why-that-matters/ (accessed on 6 February 2018).

Roser, Max, and Hannah Ritchie. 2017. Fertilizer and Pesticides. Available online: https:/ourworldindata.org/ fertilizer-and-pesticides\#yields-tend-to-increase-with-fertilizer-application (accessed on 6 February 2018).

Roser, Max, and Hannah Ritchie. 2018. Yields and Land Use in Agriculture. Available online: https:// ourworldindata.org/yields-and-land-use-in-agriculture (accessed on 6 February 2018).

Shell. 2019. Shell Pernis. Available online: https://www.shell.nl/over-ons/shell-pernis-refinery.html (accessed on 12 May 2019).

Sillanpää, Mika, and Chaker Ncibi, eds. 2017a. Legacy of petroleum-based economy. In A Sustainable Bioeconomy -The Green Industrial Revolution. Berlin/Heidelberg: Springer International Publishing AG, pp. 1-28.

Sillanpää, Mika, and Chaker Ncibi, eds. 2017b. Bioeconomy-The path to sustainability. In A Sustainable Bioeconomy -The Green Industrial Revolution. Berlin/Heidelberg: Springer International Publishing AG, pp. 29-54.

Sillanpää, Mika, and Chaker Ncibi, eds. 2017c. Implementing the bioeconomy on the ground: An international overview. In A Sustainable Bioeconomy-The Green Industrial Revolution. Berlin/Heidelberg: Springer International Publishing AG, pp. 271-316.

Sorg, Martin, Heinz Schwan, Werner Stenmans, and Andreas Müller. 2013. Ermittlung der Biomassen flugaktiver Insekten im Naturschutzgebiet Orbroicher Bruch mit Malaise Fallen in den Jahren 1989 und 2013. Mitteilungen aus dem Entomologischen Verein Krefeld 1: 1-5. Available online: https://scholar.google. $\mathrm{com} /$ scholar?q=Ermittlung+der+Biomassen+flugaktiver+Insekten+im+Naturschutzgebiet+Orbroicher+ Bruch+mit+Malaise+Fallen+in+den+Jahren+1989+und+2013+Sorg+2013 (accessed on 19 May 2019). 
Statista. 2013. Anteil der an Ausländische Investoren Verkauften Ackerflächen in Ausgewählten Entwicklungsländern im Jahr 2012. Available online: https://de.statista.com/statistik/daten/studie/ 257787/umfrage/land-grabbing-in-der-landwirtschaft-ausgewaehlter-entwicklungslaender/ (accessed on 11 February 2018).

Statista. 2018a. Global GDP (Gross Domestic Product) at Current Prices from 2010 to 2022 (in Billion U.S. Dollars). Available online: https://statista.com/statistics/268750/global-gross-domestic-product-gdp/ (accessed on 20 May 2019).

Statista. 2018b. Total Revenue of the Global Chemical Industry from 2002 to 2016 (in Billion U.S. Dollars). Available online: https://statista.com/statistics/302081/revenue-of-global-chemical-industry/ (accessed on 9 February 2018).

Statista. 2018c. Anzahl der Biogasanlagen in Deutschland. Available online: https:/de.statista.com/statistik/daten/ studie/167671/umfrage/anzahl-der-biogasanlagen-in-deutschland-seit-1992/ (accessed on 20 May 2019).

Statista. 2018d. Produktion von Zucker Weltweit in den Jahren 2010/2011 Bis 2016/2017 (in Millionen Tonnen). Available online: https://de.statista.com/statistik/daten/studie/189389/umfrage/zuckererzeugung-weltweit/ (accessed on 31 January 2018).

Statista. 2018e. Verteilung der Energiebedingten $\mathrm{CO}_{2}$-Emissionen Weltweit Nach Sektor im Jahr 2015. Available online: https:/de.statista.com/statistik/daten/studie/167957/umfrage/verteilung-der-co-emissionen-weltweitnach-bereich/ (accessed on 31 January 2018).

Statista. 2019a. Share of Economic Sectors in the Global Gross Domestic Product (GDP) from 2006 to 2016. Available online: https://www.statista.com/statistics/256563/share-of-economic-sectors-in-the-global-grossdomestic-product/ (accessed on 22 May 2019).

Statista. 2019b. Production of Major Vegetable Oils Worldwide from 2012/13 to 2018/2019, by Type (in Million Metric Tons). Available online: https://www.statista.com/statistics/263933/production-of-vegetable-oilsworldwide-since-2000/ (accessed on 4 May 2019).

Statista. 2019c. Umsatz der Chemisch-Pharmazeutischen Industrie Weltweit und in den EU-28-Staaten in den Jahren 2004 Bis 2017 (in Milliarden Euro). Available online: https:/de.statista.com/statistik/daten/studie/ 5535/umfrage/umsatz-der-chemischen-industrie-weltweit-und-in-der-eu-27/ (accessed on 22 May 2019).

Steffen, Will, Katherine Richardson, Johan Rockström, Sarah E. Cornell, Ingo Fetzer, Elena M. Bennett, Reinette Biggs, Stephen R. Carpenter, Wim de Vries, Cynthia A. de Wit, and et al. 2015. Planetary boundaries: Guiding human development on a changing planet. Science 347: 1259855. [CrossRef] [PubMed]

The Hindu. 2011. Delhi's First Bio-Gas Plant to Fuel 120 DTC Buses. Available online: http://www.thehindu.com/ todays-paper/tp-national/tp-newdelhi/delhis-first-biogas-plant-to-fuel-120-dtc-buses/article2654959.ece (accessed on 16 February 2018).

Thwaites, Joe. 2015. What Does the Paris Agreement Do for Finance? Available online: https://en.wikipedia.org/ wiki/Paris_Agreement (accessed on 31 January 2018).

Tsagkari, Mirela, Jean-Luc Couturier, Antonis Kokossis, and Jean-Luc Dubois. 2016. Early-Stage Capital Cost Estimation of Biorefinery Processes: A Comparative Study of Heuristic Techniques. Available online: https://www.ncbi.nlm.nih.gov/pubmed/?term=Couturier\%20JL\%5BAuthor\%5D\&cauthor=true\& cauthor_uid=27484398 (accessed on 11 May 2019).

Tzachor, Asaf. 2019. The future of feed: Integrating technologies to decouple feed production from environmental impacts. Industrial Biotechnology 15. Available online: https://www.liebertpub.com/doi/10.1089/ind.2019. 29162.atz (accessed on 11 May 2019). [CrossRef]

UFOP. 2017. UFOP-Bericht zur Globalen Marktversorgung 2017/2018. Available online: https://agrarheute.com/ media/2018-01/ufop-bericht_zur_globalen_marktversorgung_2017-2018.pdf (accessed on 11 January 2018).

UN. 2014. World Urbanization Prospects. Available online: https:/esa.un.org/unpd/wup/publications/files/ wup2014-highlights.pdf (accessed on 6 February 2018).

UN. 2015a. Paris Agreement. Available online: https://unfccc.int/sites/default/files/english_paris_agreement.pdf (accessed on 4 May 2019).

UN. 2015b. Transforming Our World: The 2030 Agenda for Sustainable Development. Available online: https://sustainabledevelopment.un.org/content/documents/21252030\%20Agenda\%20for\% 20Sustainable\%20Development\%20web.pdf (accessed on 22 May 2019).

UN. 2017. World Population Prospects the 2017 Revision. Available online: https://esa.un.org/unpd/wpp/ Publications/Files/WPP2017_KeyFindings.pdf (accessed on 19 May 2019). 
UN. 2018. Global Issues: The Global Energy Mix and Its Role in $\mathrm{CO}_{2}$ Emissions Mitigation. Available online: https:/www.un.org/development/desa/dpad/wp-content/uploads/sites/45/publication/Monthly_ Briefing_121.pdf (accessed on 11 May 2019).

UNEP. 2015. The Financial System We Need. Aligning the Financial System with Sustainable Development. Available online: http://unepinquiry.org/publication/inquiry-global-report-the-financial-system-we-need/ (accessed on 19 May 2019).

USEPA. 2014. Global Emissions by Economic Sector. Available online: https://www.epa.gov/ghgemissions/globalgreenhouse-gas-emissions-data (accessed on 20 February 2018).

USDA. 2014. Global Phosphate Rock Reserves and Resources, the Future of Phosphate Fertilizer. Available online: https://www.usda.gov/oce/forum/past_speeches/2014_Speeches/Kauwenbergh.pdf (accessed on 11 February 2018).

US Grains Council. 2017. Ethanol Market and Pricing Data. September 6. Available online: https://www.grains. org/ethanol-reports/20170906/ethanol-market-and-pricing-data-september-6-2017 (accessed on 20 February 2018).

VCI. 2017a. Rohstoffbasis der Chemischen Industrie. Available online: https://.vci.de/vci/downloads-vci/topthema/daten-fakten-rohstoffbasis-der-chemischen-industrie.pdf (accessed on 9 February 2018).

VCI. 2017b. Rohstoffbasis der Chemischen Industrie. Available online: https://vci.de/vci/downloads-vci/topthema/argumente-positionen-rohstoffbasis-der-chemischen-industrie.pdf (accessed on 21 May 2019).

VCI. 2018. Chemiewirtschaft in Zahlen Online. Table 67b. Available online: https://www.vci.de/die-branche/ zahlen-berichte/chemiewirtschaft-in-zahlen-online.jsp (accessed on 25 February 2018).

Ville de St. Hyacinthe. 2017. Environnement et Matières Résiduelles. Available online: http://.ville.st-hyacinthe. qc.ca/services-aux-citoyens/biomethanisation.php (accessed on 13 February 2018).

Vogel, Gretchen. 2017. Where Have All the Insects Gone? Science. Available online: http://sciencemag.org/news/ 2017/05/where-have-all-insects-gone (accessed on 9 February 2018).

Wackerbauer, Johann, and Jana Lippelt. 2011. Kurz zum Klima: Biokraftstoffe Holen auf. ifo-Schnelldienst. Available online: http://cesifo-group.de/DocDL/ifosd_2011_11_4.pdf (accessed on 11 February 2018).

Wagemann, Kurt. 2012. Roadmap Bioraffinerien. Berlin: Deutsche Bundesregierung, p. 104. Available online: https://www.bmel.de/SharedDocs/Downloads/Broschueren/RoadmapBioraffinerien.pdf?_blob= publicationFile (accessed on 22 February 2018).

WEC. 2017. World Energy Resources Bioenergy 2016. Available online: https://worldenergy.org/wp-content/ uploads/2017/03/WEResources_Bioenergy_2016.pdf (accessed on 20 May 2019).

Wagner, Bernd. 2017. Green Economy-Recherche Ist-Stand Nachhaltige Finanzwirtschaft. Available online: http://www.forumng.org/images/stories/Publikationen/FNG_Kurzanalyse_Nachhaltige_ Finanzwirtschaft_Januar_2017.pdf (accessed on 18 February 2018).

Wilson, Edward O. 2016. Half-Earth. Our Planet's Fight for Life. New York: Liveright Publishing Corp.

Woods, Jeremy, Lee R. Lynd, Mark Laser, Mateus Batistella, Daniel de Castro Victoria, Keith Kline, and André Faaij. 2015. Land and Bioenergy. In Bioenergy \& Sustainability: Bridging the Gaps. Edited by Glaucia C. Souza, Reynaldo Victoria, Carlos A. Joly and Luciano Martins Verdade. Sao Paulo: SCOPE, vol. 72, pp. 259-300.

World Resources Institute. 2018. Understanding the IPCC Reports. Available online: http://.wri.org/ipccinfographics (accessed on 31 January 2018).

Worldwatch Institute. 2018. Fish Farming Continues to Grow as World Fisheries Stagnate. Available online: http://worldwatch.org/node/5444 (accessed on 12 February 2018).

Wortmann, Erik. 2015. Global Land Use Change. Available online: https://sites.google.com/a/skagwayschool. org/bird-on-a-string/environmental-science/environmental-science-announcement/ (accessed on 6 February 2018).

WWF. 2017. Living Planet Report 2016. Available online: http://awsassets.panda.org/downloads/lpr_living planet_report_2016_summary.pdf (accessed on 22 February 2018).

WWF, Credit Suisse, and McKinsey. 2014. Conservation Finance-Moving beyond Donor Funding toward an Investor-Driven Approach. Available online: https://www.cbd.int/financial/privatesector/g-private-wwf.pdf (accessed on 22 May 2019). 
Zabel, Florian, Birgitta Putzenlechner, and Wolfram Mauser. 2014. Global agricultural land resources-A high resolution suitability evaluation and its perspectives until 2100 under climate change conditions. PLOS ONE 9: e107522. Available online: http://journals.plos.org/plosone/article?id=10.1371/journal.pone.0107522 (accessed on 22 February 2018). [CrossRef] [PubMed]

Zeug, Walther, Alberto Besamt, Urs Moesenfechtel, Anne Jäckel, and Daniela Thrän. 2019. Stakeholder's interests and perceptions of bioeconomy monitoring using a sustainable development goal framework. Sustainability 11: 1511. [CrossRef]

Zinke, Olaf. 2017. Zuckerpreise Erneut Abgestürzt. Agrarheute. Available online: https://www.agrarheute.com/ markt/marktfruechte/zuckerpreise-erneut-abgestuerzt-541197 (accessed on 18 February 2018).

(C) 2019 by the author. Licensee MDPI, Basel, Switzerland. This article is an open access article distributed under the terms and conditions of the Creative Commons Attribution (CC BY) license (http://creativecommons.org/licenses/by/4.0/). 